\title{
IFRS Adoption, Extent of Disclosure, and Perceived Corruption: A Cross-country Study
}

\author{
Muhammad Nurul Houqe \\ Senior Lecturer in Accounting \\ School of Accounting \& Commercial Law \\ Victoria Business School \\ Victoria University of Wellington \\ Email: +noor.houqe@vuw.ac.nz \\ Phone: +6444636591 \\ Fax: +6444635076 \\ $\&$ \\ Reza M Monem \\ Associate Professor in Accounting \\ Department of Accounting, Finance and Economics \\ Griffith University \\ Phone +61 737353598 \\ Fax: +61737353719 \\ E r.monem@griffith.edu.au
}

\section{Acknowledgement:}

We appreciate the discussion and comments provided by Professor Asheq R Rahman. We acknowledge helpful comments from the 2013 Illinois International Accounting Symposium held in Wuhan, China. We also thank the three anonymous reviewers of The International Journal of Accounting and the editor A Rashad Abdel Khalik for many constructive suggestions. 


\title{
IFRS Adoption, Extent of Disclosure, and Perceived Corruption: A Cross-country Study
}

(Accepted for publication at The International Journal of Accounting)

\begin{abstract}
:
We investigate whether IFRS adoption and the extent of disclosure in a country play any role in reducing perceived corruption, after controlling for the effects of political institutions and economic development. The sample covers 104 countries over the period 2009-2011. We find strong evidence that the length of IFRS experience and the extent of disclosure are negatively related to perceived corruption in a country. We also find that, relative to developed countries, developing countries benefit more from IFRS experience in lowering perceived corruption. Our results are robust to several sensitivity tests, including alternative models, alternative measures of perceived corruption, controlling for endogeneity, and correcting for two-way cluster-robust standard errors. Our findings are important because critics have questioned the merit of IFRS adoption by (developing) countries with weak institutional settings.
\end{abstract}

JEL classifications: M41, G38, K42

Keywords: Corruption perception; IFRS; Extent of disclosure; Accounting environment; Political institutions; Economic development 


\section{Introduction}

As of 25 August 2015, 131 jurisdictions around the world have adopted International Financial Reporting Standards (IFRS) in one form or another (Deloitte, 2015). This widespread adoption of IFRS has generated significant interest among researchers. An enormous body of literature on IFRS adoption has already emerged and is still growing. ${ }^{1}$ Interestingly, except for the members of the European Union (EU) and a handful of countries outside the EU (e.g., Australia, New Zealand), most of the countries that adopted IFRS are developing countries.

Unlike developed countries, developing countries are characterized by, inter alia, widespread corruption (e.g., Faccio, 2006; Olken \& Pande, 2011; Shleifer \& Vishny, 1993), weak rule of law (La Porta, Lopez-de-Silanes, Shleifer, \& Vishny, 1999), weak investor protection (La Porta, Lopez-de-Silanes, Shleifer, \& Vishny, 2000), and reduced financial transparency (Fan, Wei, \& Xu, 2011). As such, various studies have cast serious doubts on whether developing countries could benefit by simply embracing a set of high-quality accounting standards such as IFRS (e.g., Ball, 2006; Ball, Robin, \& Wu, 2003). Given widespread corruption in developing countries and many developing countries adopting IFRS, we are interested to know whether the adoption of IFRS plays any role in reducing perceived corruption. Although a vast literature exists on the causes and consequences of corruption and ways to control it (e.g., Ades \& Di Tella, 1996; Fisman \& Svensson, 2007; Rock \& Bonnett, 2004; Tanzi, 1998; Treisman, 2007), research literature linking corruption with

\footnotetext{
${ }^{1}$ See for example, Aharony, Barniv, \& Falk, 2010; Ahmed, Neel, \& Wang, 2013; Ball, 2006; Barth, Landsman, \& Lang, 2008; Barth, Landsman, Lang, \& Williams, 2012; Brown, 2011; Brüggemann, Hitz, \& Sellhorn, 2013; Cai, Rahman, \& Courtenay, 2014; Christensen, Lee, \& Walker, 2007; Daske, Hail, Leuz, \& Verdi, 2008; Ding, Hope, Jeanjean, \& Stolowy, 2008; Florou \& Pope, 2012; Houqe, van Zijl, Dunstan, \& Karim, 2012; Leuz, 2003; and Li, 2010.
} 
accounting is sparse. Accounting's inherent focus on efficiency, control and disclosure (Everett, Neu, \& Rahaman, 2007) suggests that accounting potentially plays an important role in reducing corruption and how a society perceives corruption.

We analyze a sample of 104 countries for the period 2009-2011. We operationalize accounting's role in perceived corruption via two proxies: (1) the length of IFRS experience of a country and (2) the extent of disclosure in a country as compiled by the World Bank (2012). We measure the length of IFRS experience by calculating the time lapse in months and years since the country adopted mandatory IFRS. We employ country-level data compiled by Kaufmann, Kraay, and Mastruzzi (2012) on perceived corruption and political institutions. The proxies for the strength of political institutions are voice and accountability, and rule of law. We find that the length of a country's experience with IFRS adoption and the extent of disclosure have negative effects on the level of perceived corruption. We also find that developing countries benefit more from IFRS experience than developed ones in reducing perceived corruption. Our results are robust to several sensitivity tests, including alternative models, alternative measures of perceived corruption, alternative samples, controlling for endogeneity, and correcting for cross-sectional and time-series dependence in the data.

We make three contributions to the literature on corruption and international accounting. First, we extend the growing literature on benefits of IFRS adoption by documenting that longer IFRS experience is associated with lower level of perceived corruption. This is a new and important finding given that the vast majority of countries adopting IFRS are developing countries where corruption is widespread. Our findings are consistent with those of Cai et al. (2014) and cast doubt on the argument that developing countries with weak institutional 
settings are least likely to benefit from IFRS adoption (e.g., Ball, 2006; Ball et al., 2003). Second, we contribute to the cross-country studies on corruption by specifying the role of accounting in perceived corruption. We find that both IFRS adoption and the extent of disclosure can explain perceived corruption in a country. Third, we make a methodological improvement over previous accounting studies that address corruption. Specifically, unlike Kimbro (2002) and DiRienzo, Das, Cort, and Burbridge (2007), we control for endogenous relations among political institutions, perceived corruption, and the accounting environment. In addition, unlike previous studies, we control for cross-sectional and timeseries dependence in the data.

The paper proceeds as follows. Section 2 provides an overview of the nature of corruption. Section 3 briefly reviews some key related studies and develops the theoretical framework linking corruption perception and the accounting environment. Section 4 proposes the research models, and explains the data and the variables used in the study. Empirical results

are presented in Section 5. Section 6 discusses several tests to assess the robustness of results. Section 7 summarizes the paper and provides some conclusions.

\section{The nature of corruption and corruption perception}

Following Shleifer and Vishny (1993), we define corruption broadly as the use of public office for unauthorized private gain. Our definition is consistent with those of Blackburn, Bose, and Haque (2006, 2010), and Everett et al. (2007): corruption is the abuse of discretionary power by bureaucratic officials who advance their own interests by engaging in unauthorized rent-seeking activities. These definitions refer to the practice of actual corruption. However, one may also refer to corruption as a general perception in a society. 
We define corruption perception as the extent to which corruption is believed to exist in a society.

Both the actual practice of corruption and corruption perception can be considered as cultural phenomena because they depend on how a society understands the rules and what constitutes a deviation (Melgar, Rossi, \& Smith, 2010). However, the level of actual corruption and corruption perception are related to each other in a complex way. The former affects the latter (Melgar et al., 2010), but the latter may exist even without the former. For example, Rose-Ackerman (2001) argues that low salaries and poor monitoring in the public sector are not only incentives for corruption but also prompt corruption perception even in the absence of corrupt practice. Moreover, high levels of perceived corruption could have more damaging effects than the actual level of corruption itself. Specifically, corruption perception generates a "culture of distrust" towards some institutions and may create a cultural tradition of gift-giving and hence, raise the actual level of corruption (Melgar et al., 2010). In this paper, we focus on corruption perception, instead of the actual level of corruption in a society.

\section{Prior studies and theoretical framework}

\subsection{Prior studies on corruption and corruption perception}

Because the notions of corruption and corruption perception are inter-related (Melgar et al., 2010), the literature about them is not clearly demarcated. Many authors have used corruption perception as a proxy for the actual level of corruption (e.g., Park, 2003; Serra, 2006; Triesman, 2007; Wu, 2005a). Hence, in this section, we simultaneously discuss both corruption and corruption-perception related studies. Moreover, due to the availability of 
several excellent review papers (e.g., Lambsdorf, 2006; Treisman, 2007), we highlight only some of the key findings in these areas.

Sandholtz and Koetzle (2000) argue that the political-economic structure of incentives and opportunities, and people's cultural orientations are the two primary factors that determine the level of corruption in a country. Their argument is reflected in Treisman's (2007) observations. Based on a survey of a decade of cross-national empirical studies since the mid-1990s, Treisman (2007, p. 211) observes, "[H]ighly developed, long-established liberal democracies, with a free and widely read press, a high share of women in government, and a history of openness to trade, are perceived as less corrupt". Furthermore, Lederman, Loayza, and Soares (2005) document that political institutions in the form of democracy, the parliamentary system, political stability, and freedom of press are associated with lower levels of corruption. These views are consistent with the findings of Ali and Isse (2003) and Paldam (2002). In particular, Ali and Isse (2003) find that education, judicial efficiency, and economic freedom are negatively related to corruption, while a country's foreign aid dependency and the size of government are positively related to corruption. In sum, there is overwhelming evidence to suggest that the strength of political institutions in a country matters in reducing the level of corruption.

In terms of economic determinants, the most significant determinant of corruption is the real gross domestic product (GDP) per capita (Paldam, 2002). Furthermore, Blackburn et al. (2006, 2010) demonstrate that, within a general equilibrium context, corruption and economic development are endogenously determined with a negative relationship between them. In one of the early studies, Tanzi (1998) identifies corruption as a major deterrent to 
economic growth and argues that some forms of state reforms are required to lower the supply of and demand for corruption. Furthermore, the most prominent channel through which the level of corruption affects economic growth is political instability (Mo, 2001). Other negative effects of corruption include the slowing down of foreign direct investment (FDI) in the host country (Shleifer \& Vishny, 1993; Smarzynska \& Wei, 2000; Wei, 2000), and misallocation of resources in the economy because of the necessary secrecy of corruption (Ehrlich \& Lui, 1999; Shleifer \& Vishny, 1993). Moreover, corruption in the host country shifts the ownership structure related to FDI towards joint ventures (Smarzynska \& Wei, 2000). Evidence also exists that corruption inversely affects the real exchange rate of a country (Bahmani-Oskooee \& Nasir, 2002). However, employing extreme-bounds analysis, Serra (2006) tests the robustness of the 16 most widely documented empirical determinants of corruption. She finds that only five variables are robustly related to perceived corruption. Perceived corruption is lower in richer countries and in countries with uninterrupted democracy where the population is mainly Protestant. On the other hand, perceived corruption is higher in countries with political instability and colonial heritage.

Prior research has also documented firm-level consequences of corruption. Using data from three world-wide surveys, Kaufmann and Wei (1999) find that firms which pay more bribes than others end up spending more management time with bureaucrats negotiating regulations, and these firms face a higher cost of capital. Furthermore, Fisman and Svensson (2007) document that bribery is negatively related to firm growth. In sum, corruption has many adverse consequences for an economy, including a lower economic growth rate, lower FDI, misallocation of resources, and a weaker foreign exchange rate. Moreover, corruption and economic development are negatively and endogenously related through the Page $\mid 8$ 
competition between growth-enhancing and socially unproductive investments (Ehrlich \& Lui, 1999).

\subsection{Prior studies: Corruption and accounting}

As already stated, the literature linking corruption and accounting is sparse. We are able to identify only four studies in this area: Everett et al. (2007), Kimbro (2002), Malagueño, Albrecht, Ainge, and Stephens (2010), and Wu (2005a). Two further studies, although not directly related to accounting, document that digital access to information can lower corruption (DiRienzo et al., 2007) and that improvement in corporate governance can be a catalyst to break the cycle of bribery and corruption (Wu, 2005b).

Everett et al. (2007) provide a theoretical framework on the relationship between accounting and the fight against corruption. They conclude that accounting can be both a potential enabler and a potential constrainer in the fight against corruption. On the other hand, Kimbro (2002) and Malagueño et al. (2010) investigate the role of accounting quality in corruption perception. Both studies conclude that the perception of corruption is negatively related to accounting quality. Kimbro (2002) employs the corruption perception index of the years 1995 to 1999 published by Transparency International (TI). She measures accounting quality as the number of accountants per 100,000 inhabitants and the Center for International Financial Analysis Research (CIFAR) reporting index based on financial statements in 1990. In contrast, Malagueño et al. (2010) use the Big 4 market share and perceived accounting quality (PAQ), sourced from the World Economic Forum (2003), as proxies for accounting quality. 
Using firm-level data that pre-date the year 2001, Wu (2005b) investigates whether firmlevel accounting practices in 12 Asian countries have any influence on the incidence of bribery (i.e., whether a firm has paid a bribe) and the amounts of bribe payments. $\mathrm{Wu}$ measures firm-level accounting practice in three ways: (1) whether a firm adopted international accounting standards (IAS), (2) whether annual financial statements have been audited by external auditors and (3) the percentage of sales not reported in the books. He finds that only the percentage of unreported sales is positively associated with both the incidence of bribery and the amounts of bribe payments. On the other hand, the adoption of IAS and audited financial statements are negatively and significantly associated only with the amounts of bribe payments. Wu's sample may have been subject to self-selection bias. Specifically, his sample pre-dates 2001 when IAS were voluntary in most countries. Firms which adopted IAS voluntarily may have been better governed. These firms were also likely to refrain from bribery because of better monitoring and control within the firm. In contrast, we investigate whether country-level mandatory adoption of IFRS has any association with perceived corruption in an economy. More importantly, our conjecture is that any effect of IFRS adoption on perceived corruption is increasing in the length of IFRS experience of a country. That is, a simple dichotomous classification of whether firms or countries have adopted IAS/IFRS can present a potentially distorted view of the underlying reality.

\subsection{Theoretical framework: Link between corruption perception and accounting environment}

The literature on corruption suggests that lack of accountability encourages corruption and that the culture of secrecy protects corruption (Shleifer \& Vishny, 1993). Following Shleifer and Vishny, we contend that these two factors are also likely to increase perceived corruption. Hence, at a broader level, via promoting disclosure and establishing 
accountability, accounting is likely to play a dual role in reducing both corruption and corruption perception. Thus, when the accounting environment in a country improves, perceived corruption is likely to decline in that country.

One of the ways in which countries with lower-quality or non-existent accounting standards can improve their accounting environment is through the adoption of IFRS (Hope, Jing, \& Tang, 2006). Mandatory adoption of IFRS potentially improves the accounting environment through four mechanisms. First, because of their mainly European and North American origin,,2 IFRS are likely to be perceived in most developing countries as highquality accounting standards. Research in the field of marketing suggests that country-oforigin plays an important role in the perceived quality of products or services (e.g., Agbonifoh \& Elimimian, 1999; Verlegh \& Steenkamp, 1999). Specifically, consumers in developing countries view products made in technologically advanced countries more positively than those made in developing countries (Agbonifoh \& Elimimian, 1999). Moreover, early adoption by the European Union (EU) and other developed countries outside the EU (e.g., Australia and Switzerland) plausibly gave the IFRS the necessary plausibility for widespread adoption. Thus, the countries which subsequently adopted the IFRS were likely to experience a decline in corruption perception as a consequence.

Second, mandatory IFRS adoption at the state level is a non-trivial commitment. Successful implementation of IFRS in a country requires not only educating preparers,

\footnotetext{
2 The International Accounting Standards Committee (IASC), the predecessor body of the International Accounting Standards Board (IASB) which promulgates IFRS, was established with professional representations from countries that included Australia, Canada, France, Germany, Japan, Mexico, Netherlands, the UK, and the US (Ball, 2006). Today, membership of the board of trustees of the IFRS Foundation, the legal entity under which IASB promulgates its standards, is more widely distributed around the world with six Trustees selected from the Asia/Oceania region, six from Europe, six from North America, one from Africa, one from South America and two from the rest of the world.
} 
auditors and users but also monitoring and enforcing the practice of new accounting standards (Preiato, Brown, \& Tarca, 2015). These are long-term commitments which require significant investments. Thus, a country's commitment to mandatorily adopt IFRS could be viewed as its government's commitment to greater accountability, transparency and disclosure. Such commitments could be perceived by citizens and non-citizens as positive steps towards reducing corruption, thereby reducing perceived corruption. In particular, Cai et al. (2014) argue that many developing countries which have adopted IFRS had low-quality or non-existent local standards. They document that countries with lower-quality local accounting standards prior to IFRS adoption benefitted more from adoption compared to countries whose local standards were very similar to IFRS before adoption. Moreover, IFRS require more comprehensive disclosure than most local accounting standards (Ding et al., 2007). Using a 441-item IFRS-based checklist, Morris, Susilowati, and Gray (2014) document that IFRS adoption improved corporate disclosure in Asia between 2002 and 2007 over and above the influence of country-level and firm-level factors. More importantly, there has been an upward trend in disclosure over time (Morris et al., 2014). ${ }^{3}$

Third, IFRS adoption helps a country to integrate to international trade and economy. Integration to international trade and economy is likely to raise local businesses' standards of business practice, especially in developing countries. Similarly, governments are likely to streamline regulations and business processes, thereby reducing the demand for corruption. For example, Gordon, Loeb and Zhu (2012) provide evidence that IFRS adoption leads to increased foreign direct investment inflows. Analyzing data from 124 countries over the

\footnotetext{
3 We have 18 countries from Asia in our sample of 104 countries. Corruption and perceived corruption are relatively high in Asia (Wu, 2005a)
}

Page | 12 
period 1996-2009, Gordon et al. (2012) document that the mandatory adoption of IFRS leads to enhanced FDI in transition economies. Márquez-Ramos (2008) finds similar results in the EU setting. Furthermore, countries with strong uncertainty avoidance stand to benefit most from IFRS adoption in terms of FDI by reducing perceived risks of investing abroad (Márquez-Ramos, 2008). There is also evidence that IFRS adoption leads to a higher degree of capital market integration (Cai \& Wong, 2010). Furthermore, the US investors' home bias decreases for countries that adopt IFRS and the reduction in home bias is larger for countries with larger differences between IFRS and their domestic accounting standards, for countries with a stricter rule of law and a common law origin, and in countries with greater incentives to report high-quality accounting information (Khurana \& Michas, 2011). There is also evidence that foreign mutual fund ownership increases for countries that mandatorily adopt IFRS (DeFond et al., 2011; Yu, 2010).

Fourth, the World Bank and other international organizations promote the IFRS or IFRSbased accounting standards as part of reform agenda, and sometimes even as a condition of financing (Alfredson, Leo, Picker, Loftus, Clark, \& Wise, 2009). The IFRS Foundation website claims, "the vision of global accounting standards has been publicly supported by many international organizations, including the G20, World Bank, IMF, Basel Committee, IOSCO, and IFAC" (2014). Although IASB does not claim that reduction of global corruption is one of its objectives, worldwide promotion of IFRS may have an indirect effect on reducing perceived corruption by improving the information environment (Horton, Serafeim, \& Serafeim, 2013) and requiring greater transparency and disclosure.

At the firm level, embracing higher-quality accounting standards (such as IFRS) and making greater disclosure are likely to reduce corrupt practices directly both on the demand 
and supply sides of corruption and thereby reduce perceived corruption. On the supply side, in an improved accounting environment, corporate executives are likely refrain from corrupt practices because it would be very difficult to hide the huge payments or irregular transactions (Wu, 2005a). On the demand side, an improved accounting environment, created by adherence to higher-quality accounting standards and higher level of corporate disclosure, is likely to deter corrupt government officials from demanding bribes because they face greater risks of being caught $(\mathrm{Wu}, 2005 \mathrm{a})$. Consequently, a reduction in the level of actual corrupt practices in a society is likely to reduce perceived corruption as well (Melgar et al., 2010).

In sum, we argue that an improved accounting environment in a country can reduce perceived corruption by promoting disclosure and establishing accountability. Developing countries can significantly improve their accounting environment by mandatory adoption of IFRS and enhanced corporate disclosure. Moreover, because of the sheer complexity of implementing and enforcing a set of new accounting standards, the benefits of IFRS adoption in reducing perceived corruption are likely to increase over time. Formally, we hypothesize that:

H1: Ceteris paribus, longer IFRS experience is positively associated with the perception of less corruption in a country.

Another way in which the accounting environment in a country is potentially linked to perceived corruption is how sensitive business transactions with conflicts of interest are reported. A typical example of such transactions would be a related-party transaction in which majority shareholders benefit at the expense of minority shareholders. How minority shareholders are protected through the transparency and disclosure of such transactions 
would to some extent reflect the perception of corporations-based corruption in that country. Specifically, because corruption is about secrecy (Shleifer \& Vishny, 1993), how a country's courts, corporation laws, and securities law deal with such business transactions in terms of their approval and disclosure potentially reflects the perception of corporationsbased corruption in that country. Naturally, greater disclosure of such sensitive transactions would be associated with lower perceived corruption. Thus, we hypothesize the following:

H2: Ceteris paribus, the extent of disclosure is positively associated with the perception of less corruption in a country.

\section{Research Design}

\subsection{Data}

Our initial sample comprises annual observations for 214 countries over the years 2009 to 2011. From this initial sample, we eliminated 31 countries whose corruption scores were not available in Kaufman et al. (2012). Then we excluded 17 countries due to missing extent of disclosure scores, one of the variables of interest. In addition, we excluded 62 countries due to the non-availability of their IFRS-adoption status. These three sets of exclusions resulted in a sample of 104 countries.

Our dependent variable is the "control of corruption" index developed by Kaufman et al. (2012) as part of the Worldwide Governance Indicators (WGI) project. ${ }^{4}$ In the WGI project, data from over 30 different sources are combined into six aggregate governance indicators

\footnotetext{
4 The WGI project collects data from sources that include "surveys of firms and households, as well as the subjective assessments of a variety of commercial business information providers, non-governmental organizations, and a number of multilateral organizations and other public-sector bodies" (Kaufmann et al., 2011, p. 224). The data sources are fairly evenly divided among these four categories (Kaufman et al., 2011). 
(i.e., voice and accountability, political stability and absence of violence/terrorism, government effectiveness, regulatory quality, rule of law, and control of corruption). Aggregate governance indicators are developed using a statistical tool known as the unobserved components model (Kaufmann et al., 2011). The WGI measures are reported in two ways: in the standard normal units of the governance indicator, ranging from around 2.5 to $2.5^{5}$, and in percentile rank terms ranging from 0 (lowest) to 100 (highest) among all countries worldwide (Kaufmann et al., 2011). ${ }^{6}$ In this paper, we focus on the "control of corruption" index expressed in standard normal units. For ease of interpretation, we label the index as Low_Corrup with higher scores indicating less perceived corruption.

Regarding perception-based corruption measures, Treisman (2007, p. 212) observes, "The more subjective indexes of perceived corruption—based on evaluations of experts and opinions of business people and citizens-turn out to be highly correlated with a variety of factors that are commonly believed to cause corruption." The views of Transparency International (2015) echo Treisman's observations:

There is no meaningful way to assess absolute levels of corruption in countries or territories on the basis of hard empirical data. Possible attempts to do so, such as by comparing bribes reported, the number of prosecutions brought or studying court cases directly linked to corruption, cannot be taken as definitive indicators of corruption levels...Capturing perceptions of corruption of those in a position to offer assessments of public sector corruption is the most reliable method of comparing relative corruption levels across countries.

\footnotetext{
${ }^{5}$ However, actual scores in our sample range from -1.439 to 2.484 . By comparison, the WGI data set has "control of corruption" scores for 212 countries in 2011 ranging from -1.70 to 2.45.

${ }^{6}$ For a detailed discussion of the methodology, see Kaumann et al. (2011). 
Another popular measure of corruption perception is the TI's Corruption Perception Index (TI CPI). We use Kaufmann et al.'s (2012) corruption perception index for our main analysis because it incorporates data from more sources than TI CPI and attempts to improve on the treatment of statistical uncertainty in TI CPI (Knack, 2007). However, we estimate all of our models using TI CPI as part of robustness tests (Section 6).

We measure IFRS experience (IFRS_EXP) as the number of years since a country has mandatorily adopted the IFRS. 7, 8 We obtain IFRS adoption dates from the "IFRS Adoption by Country" survey conducted by PricewaterhouseCoopers (PwC) in April 2013. The PwC survey covers 141 countries, and lists IFRS adoption date where available. We compute IFRS_EXP by subtracting the adoption date from the end of each calendar year in our sample (i.e., 31 December 2011 - adoption date of country $i$ and so on).

Our measure of the extent of disclosure (DISC) comes from the World Bank's measure of how well minority shareholders are protected through disclosure against self-dealing in related-party transactions. Since 2004, the World Bank has been compiling “Doing Business" reports annually, measuring regulations affecting 11 areas of the life of a business, including protection of minority investors through the transparency of related-party transactions. "The data come from a survey of corporate and securities lawyers and are based on securities regulations, company laws, civil procedure codes and court rules of evidence" (The World Bank, 2012, p. 5). The survey covers questions such as which corporate body can approve a

\footnotetext{
${ }^{7}$ There are several methods that jurisdictions can use to implement IFRS (Zeff \& Nobes, 2010). Thus, whether a particular jurisdiction actually adopted IFRS or adopted the standard setting process of the IASB can be contested (see Zeff \& Nobes (2010) for the controversy). We interpret adoption of IFRS in a broader sense regardless of the process through which such adoption took place.

8 Unlike many prior studies, we do not use IFRS adoption as a binary variable because a binary variable ignores the learning process involved in reporting under new standards and their enforcements. That is, the benefit of IFRS adoption is an increasing function of the length of IFRS adoption.
} 
related-party transaction, whether immediate disclosure of the transaction is required, whether disclosure in the annual report is required, whether disclosure to the board of directors is required, and whether an external body such as an external auditor is required to review the transaction before it takes place (The World Bank, 2012). The World Bank's measure of the extent of disclosure (DISC) ranges from 0 to 10 with higher scores indicating greater disclosure. These scores are comparable across economies and over time. In addition to using IFRS_EXP and DISC as separate variables, we aggregate them into a single variable and use this variable as a summary measure of the overall accounting environment ( $\left.A_{-} E N V\right)$ of a country.

We use voice and accountability, and rule of law as two measures of the strength of political institutions ( $\mathrm{Pol}$ ) in a country, as per Kaufmann et al. (2012). The level of economic development (ECO_DEV) is measured as the natural logarithm of GDP (in US\$) as per the World Bank (2011). Our choice of these control variables is motivated by strong evidence, as already documented in Section 3.1, that political institutions and economic development of a country are related to the level of actual corruption as well as perceived corruption. Table 1 provides the list of all the variables in this study, their detailed definition, and data sources.

\section{(Insert Table 1 here)}

\subsection{Models}

Our objective in this study is to understand the relationship between the length of IFRS experience (IFRS_EXP) and the extent of disclosure (DISC) in a country with its level of perceived corruption after controlling for the strength of political institutions and the level of economic development. We do not aim to identify all institutional variables related to 
corruption. Hence, we propose parsimonious models. First, we propose a benchmark model of explaining perceived corruption on the basis of the strength of political institutions and the level of economic development:

Low_Corrup $=\alpha_{0}+\alpha_{1}($ Pol $)+\alpha_{2}\left(E C O \_D E V\right)+\varepsilon$

where all variables are as defined in Table 1.

Next we extend model (1) to incorporate $A_{-} E n v$ as our variable of interest:

Low_Corrup $=\alpha_{0}+\alpha_{1}($ Pol $)+\alpha_{2}\left(E C O \_D E V\right)+\alpha_{3}\left(A_{-} E N V\right)+\varepsilon$

where all variables are as defined in Table 1 . A positive and significant $\alpha_{3}$ would be consistent with our expectation. Next, we replace $A_{-} E N V$ with $I F R S \_E X P$ and DISC in alternative specifications to assess their incremental contribution to corruption perception:

Low_Corrup $=\dot{\alpha}_{0}+\dot{\alpha}_{1}($ Pol $)+\dot{\alpha}_{2}\left(E C O \_D E V\right)+\dot{\alpha}_{3}\left(I F R S \_E X P\right)+\varepsilon$

Low_Corrup $=\dot{\alpha}_{0}+\dot{\alpha}_{1}($ Pol $)+\dot{\alpha}_{2}\left(E C O \_D E V\right)+\dot{\alpha}_{3}($ DISC $)+\varepsilon$

where all variables are as defined in Table 1. Now we incorporate IFRS_EXP and DISC in the same model:

Low_Corrup $=\psi_{0}+\psi_{1}(\mathrm{Pol})+\psi_{2}\left(E C O \_D E V\right)+\psi_{3}($ IFRS_EXP $)+\psi_{4}($ DISC $)+\varepsilon$

where all variables are as defined in Table 1. Consistent with prior research, we expect positive coefficients on $P o l$ and $E C O \_D E V$ in all models. In models (3), (4) and (5), positive and significant coefficients on IFRS_EXP and DISC would be consistent with $\mathrm{H} 1$ and $\mathrm{H} 2$, respectively.

\subsection{Descriptive statistics}

Table 2 provides descriptive statistics of the key variables used in this study. As Table 2 reveals, over the period 2009-2011 (312 country-years), the corruption perception index (Low_Corrup) ranges in our sample from -1.439 (perceived as the most corrupt country) to 2.484 (perceived as the least corrupt country). Thus, in our sample, the average country is highly corrupt with a mean (median) score of $0.278(0.096)$ sitting at around $11.19 \%$ 
(2.45\%) of the scale. The sample countries with their corruption perception scores over the period 2009-2011 are reported in Appendix 1.

In Table 2, the mean (median) voice and accountability $\left(V_{-} A\right)$ score over the period 20092011 is $0.201(0.409)$ with the minimum of -2.158 and the maximum of 1.630 . In terms of rule of law $\left(R_{-} L A W\right)$, the mean (median) score over the period 2009-2011 is $0.246(0.147)$ with the minimum of -1.820 and the maximum of 1.970 . Over the $2009-2011$ period, the mean (median) score of IFRS experience (IFRS_EXP) is $3.830(5.000)$ years in a scale that ranges from 0.000 (non-adopters of IFRS) to 11.000 years (earliest adopters of IFRS in our sample). The extent of disclosure index (DISC) ranges from 1.000 to 10.000 with the mean (median) score of 5.706 (6.075). The mean (median) GDP per capita is US $\$ 17,375.31$ $(\$ 8,292.46)$ with the minimum being US $\$ 323.45$ and the maximum US\$100,541.24. Summary statistics of the variables in each individual year are very much consistent with those of the combined sample period (2009-2011).

\section{(Insert Table 2 here)}

Table 3 presents the Pearson's correlation matrix for the combined sample (2009-2011) as well as the samples of individual years. In the combined sample (Panel A), among all the variables, corruption perception index (Low_Corrup) has the strongest positive correlation with IFRS experience ( $r=0.568$ ) followed by the level of economic development $(r=0.471)$, rule of law $(r=0.346)$, voice and accountability $(r=0.242)$, and the extent of disclosure $(r=$ 0.230). All of these correlations are significant at the $1 \%$ level. Among the other variables, IFRS experience is positively and significantly related to voice and accountability $(r=0.201)$, rule of law $(r=0.260)$, and the level of economic development $(r=0.285)$, all significant at the $1 \%$ level. Note that the extent of disclosure is significantly correlated with rule of law $(r$ 
$=0.230$, significant at the $1 \%$ level $)$ but not with IFRS experience $(r=0.061)$ at any conventional level. The absence of significant correlation between the extent of disclosure and IFRS experience increases our confidence that these two variables capture different aspects of the accounting environment in a country. The correlation coefficients reported for individual years in Panels B (2011), C (2010), and D (2009) are consistent with those reported in Panel A.

\section{(Insert Table 3 here)}

\section{Results}

\subsection{Main results}

Table 4 reports the OLS estimates of models (1) to (5) for the year 2011. In the benchmark model (1), the adjusted $R^{2}$ is $73.5 \%$. That is, together the strength of political institutions $(\mathrm{Pol})$ and the level of economic development (ECO_DEV) explain $73.5 \%$ of the variations in country-level perceived corruption (Low_Corrup). Besides, the positive coefficients on these variables, as expected, suggest that stronger political institutions and higher economic development are associated with lower perceived corruption. In model (2), we introduce the variable accounting environment $\left(A_{-} E N V\right)$. The coefficient of 0.039 on $A_{-} E N V$ is positive as expected and statistically significant $(t$-statistic $=2.629)$ at the $1 \%$ level. ${ }^{9}$ These results suggest that a stronger accounting environment (via IFRS experience and greater disclosure) is associated with lower levels of perceived corruption.

As Table 4 shows, in model (3), the coefficient of 0.048 on the length of IFRS experience $($ IFRS_EXP $)$ is positive and significant $(t$-statistic $=2.954)$ at the $1 \%$ level. Thus, over a five-

\footnotetext{
${ }_{9}^{9}$ All statistical tests in this study except those reported in Table 3 are one-tailed tests. 
year period ${ }^{10}$ IFRS experience is likely to increase the corruption perception score of a country by $0.24(=0.048 \times 5)$. Based on Kaufmann et al.'s 2011 corruption perception scores, such an increase would place a country about twelve places higher (indicating perception of lesser corruption) in the global ranking of corruption perception compared to a nonadopter-country of IFRS.

In model (4), we substitute IFRS_EXP with the extent of disclosure (DISC) and find that DISC is positive and significant $(t$-statistic $=1.765)$ at the $5 \%$ level. Next, in model (5), we incorporate both the variables IFRS_EXP and DISC. Consistent with prior results, the variables IFRS_EXP $(t$-statistic $=2.111)$ and DISC $(t$-statistic $=1.891)$ are both positive as expected and significant at the 5\% level. Thus, in all estimations, although Pol and ECO_DEV are the most influential variables (i.e., the largest coefficients with the strongest $t$-statistics), the accounting variables IFRS_EXP and DISC still have some power in explaining perceived corruption. Thus, $\mathrm{H} 1$ and $\mathrm{H} 2$ are supported.

\section{(Insert Table 4 here)}

All results in Tables 5 (year 2010) and 6 (year 2009) are qualitatively similar to those reported in Table 4 (year 2011). Consistent results on all of the five models across the three years enhance our confidence in the results.

\section{(Insert Table 5 here)}

\section{(Insert Table 6 here)}

\subsection{Further analysis}

We further investigate whether developing countries benefit more from IFRS adoption relative to developed countries. Accordingly, we transform the continuous variable

${ }^{10}$ Median IFRS experience in our total sample is 5 years.

Page | 22 
economic development (ECO_DEV) into a dichotomous variable (Developing) by setting lowincome countries equal to 1 (i.e., countries with per capita GDP below US\$4,528 in 2009, below US $\$ 4,887$ in 2010 , and below US $\$ 5,203$ in 2011$)^{11}$ and 0 for other countries. We also introduce an interaction variable to test whether the length of IFRS experience between developing (coded 1) and developed countries (coded 0) makes any difference to the perception of corruption. Thus, our empirical model is:

$$
\begin{aligned}
\text { Low_Corrup }=\dot{\alpha}_{0}+\dot{\alpha}_{1} & (\text { Pol })+\dot{\alpha}_{2} \text { (Developing) } \\
& +\dot{\alpha}_{3}(\text { IFRS_EXP })+\dot{\alpha}_{4}\left(\text { Developing }{ }^{*} \text { IFRS_EXP }\right)+\dot{\alpha}_{5}(\text { DISC })+\varepsilon
\end{aligned}
$$

where all variables are as defined in Table 1.

Because we coded developing countries as 1, we expect a negative coefficient on the variable Developing. This expectation is based on the evidence that developing countries are more corrupt than developed countries. Table 7 reports the results of OLS estimates of model (9) separately for each year $(2011,2010$, and 2009).

Table 7 shows that the coefficients of Developing are negative and significant at the $5 \%$ level in 2010 and 2011 (coefficient $=-0.238,-0.240 ; t$-statistic $=1.687,1.689$; respectively) and significant at the $10 \%$ level in 2009 (coefficient $=-0.220$; $t$-statistic $=1.625$ ). These results are consistent with our expectation because developing countries have higher perceived corruption (e.g., Blackburn et al., 2010; Treisman, 2007). The coefficients on IFRS experience are positive and statistically significant at the $1 \%$ level in all three estimates (coefficient $=0.077,0.081,0.077 ; t$-statistic $=2.584,2.908,2.589 ;$ respectively). The

\footnotetext{
${ }^{11}$ A developing country (also known as a less-developed country) is a country with a lower living standard, underdeveloped industrial base, and low Human Development Index compared to other countries. We use 2009, 2010, and 2011 GPD per capita (based on 2005 purchasing power parity) for medium human development countries as the cut-off point for our classification system. Countries below this cut-off are coded as 1 (developing) and those above the cut-off as 0 .
} 
interaction variable Developing * IFRS_EXP is consistently positive and significant at the $1 \%$ level across all years (coefficient $=0.088,0.101,0.098 ; t$-statistic $=2.984,2.587,2.684$; respectively). These results suggest that developing countries with IFRS experience have relatively lower corruption perception compared to developed countries with IFRS experience. For example, based on the estimates in 2011, a one-year experience of IFRS for a developing country improves the corruption perception score by $0.165(=0.077+0.088) .{ }^{12}$ By comparison, in a developed country that has a similar IFRS experience, the corruption perception score improves just by 0.077 . In other words, all else being equal, developing countries benefit more in terms of lower perceived corruption due to IFRS experience compared to developed countries. One plausible explanation is that developed countries already had high-quality accounting standards before IFRS adoption and hence, the incremental benefit of IFRS adoption is marginal in developed countries.

\section{(Insert Table 7 here)}

Our findings are consistent with those in Cai et al. (2014) and cast doubts on the criticism that, due to weak institutional arrangements, developing countries are unlikely to benefit from IFRS adoption (e.g., Ahmed et al. 2013; Ball, 2006; Ball et al., 2003). When financial reporting quality of developing countries following IFRS adoption is compared to that of developed countries, the reporting quality may not exhibit the same standard as that in developed countries. However, whatever improvement in reporting occurs can have a relatively larger impact on the developing countries.

12 The coefficients of the variable Developing * IFRS_EXP are stronger in 2010 and 2009 (0.101 and 0.098, respectively). 
In sum, our results clearly demonstrate that longer IFRS experience can benefit developing countries by reducing the perception of corruption. All else being equal, perception of corruption is likely to be strongly correlated with corruption experience of the people in a country (e.g., Kimbro, 2002; Treisman, 2007). Thus, we document a benefit of IFRS adoption, especially in developing countries, which has not been documented in the literature to date.

\section{Robustness checks}

In this section, we report the results of several sensitivity tests to check the robustness of our main results. First, we control for potentially endogenous relations among corruption perception, political institutions, and accounting environment. In prior studies, although DiRienzo et al. (2007), Kimbro (2002), and Malagueño et al. (2010) recognized the presence of such endogeneity, they could not test it due to data limitation. We address this endogeneity issue by employing the 2SLS technique on models (7), (8), and (9).

Our empirical models are as follows:

$$
\begin{aligned}
& \text { Low_Corrup }=\alpha_{0}+\alpha_{1}(\text { Pol })+\alpha_{2}\left(E C O_{-} D E V\right)+\alpha_{3}\left(A_{-} E N V\right)+\varepsilon \\
& A_{-} E N V=\dot{\alpha}_{0}+\dot{\alpha}_{1}(\text { Pol })+\dot{\alpha}_{2}\left(E C O \_D E V\right)+\dot{\alpha}_{3}(\text { Low_Corrup })+\varepsilon \\
& \text { Pol }=\alpha_{0}+\alpha_{1}\left(E C O \_D E V\right)+\alpha_{2}\left(A_{-} E N V\right)+\alpha_{3}(\text { Low_Corrup })+\varepsilon
\end{aligned}
$$

where all the variables are as defined in Table 1.

We estimate these models for each year separately, but, for brevity, report only the 2011 results in Table 8. As Table 8 reveals, the results of the 2SLS regressions are largely consistent with those of the OLS regressions reported in Table 4. In model (7), stronger political institutions ( $t$-statistic of $\mathrm{Pol}=9.954$, significant at $1 \%$ ), and better accounting environments ( $t$-statistic of $A_{-} E N V=3.128$, significant at $1 \%$ ) are both associated with the 
perception of lower corruption. Furthermore, positive and statistically significant coefficient on $E C O \_D E V$ ( $t$-statistic $=2.129$, significant at $\left.5 \%\right)$ is consistent with prior research that developed countries have lower levels of corruption (e.g., Kimbro, 2002; Treisman, 2007). In model (7) where $A_{-} E N V$ is the dependent variable, both the corruption perception index $(t-$ statistic $=3.245)$ and the strength of political institutions $(t$-statistic $=7.458)$ are positive and statistically significant at the $1 \%$ level. These results are consistent with previous findings (e.g., Kimbro, 2002; Malagueño et al., 2010) that low level of corruption perception is associated with strong political institutions and improved accounting environment. In model (8), ECO_DEV ( $t$-statistic $=5.421), L_{0}{ }_{-}$Corrup $(t$-statistic $=8.521)$ and $A_{-} E N V(t$-statistic $=3.101$ ) are all positive and statistically significant at the $1 \%$ level. In sum, results in Table 8 confirm that, after controlling for endogenous relations among corruption perception, the strength of political institutions, and accounting environment, improved accounting environment is associated with lower levels of perceived corruption.

\section{(Insert Table 8 here)}

Second, we re-estimate our model (5) on the combined sample (2009-2011) after correcting for two-way cluster-robust standard errors (CL-2): one for cross-sectional correlation (country-level) and one for serial correlation (year-level). Un-tabulated results suggest that our main results still hold. That is, IFRS experience $(t$-statistic $=2.670$, significant at $1 \%$ level) and the extent of disclosure ( $t$-statistic $=2.420$, significant at $1 \%$ level) are positively related to lower levels of perceived corruption.

Third, following prior research, we control for several institutional factors that are potentially related to perceived corruption. In alternative models, we control for the type of the political system (Rose-Ackerman, 2001; Sung, 2004), the taxation regime (Tanzi \& 
Davoodi, 2001), investor protection (La Porta et al., 2000), and cultural values (Getz \& Volkema, 2001; Husted, 1999).

$$
\begin{aligned}
& \text { Low }{ }_{-} \text {Corrup }=\psi_{0}+\psi_{1}(\text { DEMOCRACY })+\psi_{2}\left(E C O \_D E V\right) \\
& +\psi_{3}\left(I F R S_{-} E X P\right)+\psi_{4}(D I S C)+\psi_{5}\left(I N V_{-} P R O\right)+\varepsilon \\
& \text { Low_Corrup }=\psi_{0}+\psi_{1}(\text { DEMOCRACY })+\psi_{2}\left(E C O \_D E V\right) \\
& +\psi_{3}\left(I F R S_{-} E X P\right)+\psi_{4}(D I S C)+\psi_{5}\left(I N V_{-} P R O\right)+\psi_{6}\left(T X_{-} R A T E\right)+\varepsilon \\
& \text { Low_Corrup }=\psi_{0}+\psi_{1}(\text { DEMOCRACY })+\psi_{2}\left(E C O \_D E V\right) \\
& +\psi_{3}\left(I F R S_{-} E X P\right)+\psi_{4}(D I S C)+\psi_{5}\left(I N V_{-} P R O\right)+\psi_{6}(C U L)+\varepsilon
\end{aligned}
$$

where DEMOCRACY is a dummy variable set equal to 1 for democratic countries (U.S. CIA, 2011), INV_PRO refers to the level of investor protection in a country (The World Bank, $2009,2010,2011$ ) and CUL refers to various culture dimensions as per Hofstede (2011); all other variables are as defined in Table 1.

Table 9 presents the results of estimating models (10), (11), and (12) over the period 2009-2011 using the OLS technique. In all of the regressions, the coefficients of both IFRS_EXP and DISC are positive and significant at the $1 \%$ level. Results for the control variables are broadly consistent with prior research (e.g., Getz \& Volkema, 2001; Husted, 1999; Sung, 2004) and with our expectation. Specifically, perceived corruption is lower in countries that are democratic, countries that have stronger investor protection, and countries with strong individualism. In contrast, perceived corruption is higher in countries with large power distance, countries with strong uncertainty avoidance, and countries that are secretive.

Fourth, we re-estimate model (5) using TI CPI as a further robustness test for our key results. Our key results remain qualitatively similar (un-tabulated). Specifically, the variable IFRS_EXP $(t$-statistic $=1.704,1.698,1.701)$ is positive and significant at the $5 \%$ level across all the three years. Moreover, the variable DISC $(t$-statistic $=3.051,2.778,2.996)$ is positive 
and significant at the $1 \%$ level across all the three years. Our results based on TI CPI are not surprising given strong correlation $(>0.98$ ) between Kaufmann et al.'s corruption perception index and that of TI.

Finally, we regress the changes in corruption perception index on a time index to gauge whether corruption in general has been declining over time. ${ }^{13}$ We do this to rule out the possibility that the variable IFRS_EXP (which is increasing in time) is not simply a proxy for the time index. We find that change in corruption perception index across the years 20092011 is not significantly related to time. This finding enhances our confidence that our variable of interest IFRS_EXP is not capturing some correlated omitted variable.

In sum, all of our sensitivity tests provide consistent evidence that IFRS experience and the extent of disclosure are inversely related to perceived corruption in a country. More importantly, developing countries benefit more from IFRS experience in terms of its effect on perceived corruption than do developed countries.

\section{Conclusion}

In this paper, we employ cross-country data to investigate the link between corruption and accounting environment. In particular, we investigate whether perception of corruption is associated with the length of IFRS experience of a country and the extent of disclosure. We are motivated by the paucity of research in this area despite accounting's fundamental focus

\footnotetext{
13 To undertake this analysis, we subtract the 2008 scores of corruption perception index from 2011 scores, from 2010 scores, and from 2009 scores and assign time indicators of 3 (2011-2008), 2 (2010-2008), 1(20092008), respectively, to these corruption score changes. Then we regress the corruption perception score changes on the time index.
} 
on efficiency, control, and disclosure. We are also motivated by the controversy surrounding IFRS adoption by developing countries with weak institutional settings.

Our sample covers 104 countries over the period 2009-2011. We pool together data related to corruption perception, the strength of political institutions (voice and accountability, and rule of law), economic development, and the extent of disclosure from World Bank reports. We compute the length of IFRS experience of a country based on the PwC (2013) report that lists IFRS adoption date for 141 countries. Across several tests, we find consistent and robust evidence that perception of low corruption is positively related to the length of IFRS experience and the extent of financial disclosure after controlling for the strength of political institutions and the level of economic development. We also find that developing countries benefit more from IFRS experience compared to developed countries.

Our results are robust to alternative specifications of our models, alternative measures of perceived corruption, alternative samples, controlling for endogeneity, and correcting for cross-sectional and time-series dependence in the data. Thus, we document a new benefit of IFRS adoption, and especially for developing countries. Our results are consistent with those in Cai et al. (2014) and cast doubts on the argument that developing countries with weak institutional settings do not benefit from IFRS adoption (e.g., Ahmed et al., 2013; Ball, 2006; Ball et al., 2003).

Although our results are strong and consistent, they need to be interpreted with some caution. First, like most cross-country studies, we pooled data from different sources that collect and disseminate data for different purposes. Thus, construct validity of some of our proxies might be an issue. Second, our results could be sensitive to alternative proxies for 
the variables used in the study. Third, although we show a link between IFRS adoption and perception of corruption, we do not specify the channels through which perception of corruption changes. Future research may attempt to identify these channels. 


\section{References}

Ades, A., \& Di Tella, R. (1996). The causes and consequences of corruption: A review of recent empirical contributions. IDS Bulletin, 27(2), 6-11.

Ahmed, S.A., Neel, M., \& Wang, D. (2013). Does mandatory adoption of IFRS improve accounting quality? Preliminary evidence. Contemporary Accounting Research, 30(4), 1344-1372.

Agbonifoh, B.A., \& Elimimian, J.U. (1999). Attitudes of developing countries towards "country-of-origin" products in an era of multiple brands. Journal of International Consumer Marketing, 11(4), 97-116.

Aguilera, R.V., \& Cuervo-Cazurra, A. (2009). Codes of good governance. Corporate Governance: An International Review, 17(3), 376-387.

Aharony, J. Barniv, R. and Falk, H. 2010. The impact of mandatory IFRS adoption on equity valuation of accounting numbers for security investors in the EU. European Accounting Review, 19(3):535-578.

Aidt, T. K. (2003). Economic analysis of corruption: A survey. The Economic Journal, 113 (491), F632-F652.

Alfredson, K., Leo, K., Picker, R., Loftus, J., Clark, K. \& Wise, V. (2009). Applying International Financial Reporting Standards (2 ${ }^{\text {nd }}$ Ed.), John Wiley \& Sons, Milton, Qld, Australia.

Ali, A. M., \& Isee, H. (2003). Determinants of economic corruption: A cross-country comparison. Cato Journal, 22(3), 449-466.

Ashbaugh, H., \& Pincus, M. (2001). Domestic accounting standards, international accounting standards and the predictability of earnings. Journal of Accounting Research, 39(3), 417434.

Bahmani-Oskooee, M., \& Nasir, A. (2002). Corruption, law and order, bureaucracy, and real exchange rate. Economic Development and Cultural Change, 50(4), 1021-1028.

Ball, R. (2006). International Financial Reporting Standards (IFRS): Pros and cons for investors. Accounting \& Business Research, 36(Sup.1), 5-27. 
Ball, R., Robin, A., \& Wu, J.S. (2003). Incentives versus standards: Properties of accounting income in four East Asian countries. Journal of Accounting and Economics, 36(1-3), 235270.

Barth, M., Landsman, W., \& Lang, M. (2008). International accounting standards and accounting quality. Journal of Accounting Research, 46(3), 467-498.

Barth, M. E., Landsman, W. R., Lang, M. H., and Williams, C. (2012). Are IFRS-based and US GAAP-based accounting amounts comparable? Journal of Accounting and Economics, 54, 68-93.

Blackburn, K., Bose, N., \& Haque, M.E. (2006). The incidence and persistence of corruption in economic development. Journal of Economic Dynamics \& Control, 30(12), 2447-2467.

Blackburn, K., N. Bose, \& Haque, M.E. (2010). Endogenous corruption in economic development. Journal of Economic Studies 37(1), 4-25.

Brüggemann, U., Hitz, J., and Sellhorn, T. (2013). Intended and unintended consequences of mandatory IFRS adoption: a review of extant evidence and suggestions for future research. European Accounting Review, 22(1), 1-37.

Brown, P. (2011). International financial reporting standards: What are the benefits? Accounting and Business Research, 41(3), 269-285.

Cai, L., Rahman, A., \& Courtenay, S. (2014). The effect of IFRS adoption conditional upon the level of pre-adoption divergence. The International Journal of Accounting, 49(2), 147178.

Campos, J. E., Lien, D., \& Pradhan, S. (1999). The impact of corruption on investment: Predictability matters. World Development, 27(6), 1059-1067.

Christensen, H. B., Lee, E., and Walker, M. (2007). Cross-sectional variation in the economic consequences of international accounting harmonization: The case of mandatory IFRS adoption in the U.K. The International Journal of Accounting, 42, 341-379.

Christensen, H.B., Hail, L., \& Leuz, C. (2013). Mandatory IFRS reporting and changes in enforcement. Journal of Accounting and Economics, 56(2-3), Supplement 1, 147-177.

Daske, H., Hail, L., Leuz, C., \& Verdi, A. (2008). Mandatory IFRS reporting around the world: Early evidence on the economic consequences. Journal of Accounting Research, 46(5), 1085-1142.

Page | 32 
Deegan, C. (2009). Financial Accounting Theory, 3rd edition, McGraw Hill Book Company, Sydney.

Deloitte. (2015). Use of IFRS by jurisdiction. Available at http://www.iasplus.com /Plone/en/resources/use-of-ifrs (last accessed on 25 August 2015)

Ding, Y., Hope, O.K., Jeajean, T., \& Stolowy, H. (2007). Difference between domestic accounting standards and IAS: Measurement, determinant and implications. Journal of Accounting and Public Policy, 26(1), 1-38.

DiRienzo, E., Das, J., Cort, K.T., \& Burbridge, J. (2007). Corruption and the role of information. Journal of International Business Studies, 38(2), 320-332.

Ehrlich, I., \& Lui, F. T. (1999). Bureaucratic corruption and endogenous economic growth. Journal of Political Economy, 107(S6), S270-S293.

Everett, J., Neu, D., \& Rahaman A.S. (2007). Accounting and the global fight against corruption. Accounting, Organizations and Society, 32(6), 513-542.

Faccio, M. (2006). Politically-connected firms. American Economic Review, 96(1), 369-386.

Fan, J. P. H., Wei, K. C. J., \& Xu, X. (2011). Corporate finance and governance in emerging markets: A selective review and an agenda for future research. Journal of Corporate Finance, 17, 207-214.

Fisman, R., \& Svensson, J. (2007). Are corruption and taxation really harmful to growth? Firm level evidence. Journal of Development Economics, 83(1), 63-75.

Florou, A., and Pope, P.F. (2012). Mandatory IFRS adoption and institutional investment decisions, The Accounting Review, 87(6):1993-2025.

Getz, K. A., \& Volkema, R. J. (2001). Culture, perceived corruption, and economics. Business \& Society, 40(1), 7-30.

Gow, I.D., Ormazabal, G., \& Taylor, D.J. (2010). Correcting for cross-sectional and time-series dependence in accounting research. The Accounting Review, 85(2), 483-512.

Habib, M., \& Zurawicki, L. (2002). Corruption and foreign direct investment. Journal of International Business Studies, 33(2), 291-307. 
Hofstede, G. (2011). Dimensionalizing cultures: The Hofstede model in context. Online Readings in Psychology and Culture, 2(1). Available at http://dx.doi.org/10.9707/2307$\underline{0919.1014}$

Hope, O.K., Jin, J., \& Kang, T. (2006). Empirical evidence from jurisdictions that adopt IFRS. Journal of International Accounting Research, 5(2), 1-20.

Horton, J., Serafeim, G and Serafeim, I. (2013). Does mandatory IFRS adoption improve the information environment? Contemporary Accounting Research, 30(1):388-423.

Houqe, M.N., van Zijl, T., Dunstan, K., \& Karim, W. (2012). The effect of IFRS adoption and investor protection on earnings quality around the world. The International Journal of Accounting, 47(3), 333-355.

Husted, B. W. (1999). Wealth, culture, and corruption. Journal of International Business Studies, 30(2), 339-359.

IFRS Foundation. (2014). IFRS application around the world. Available at http://www.ifrs.org/Use-around-the-world/Pages/Jurisdiction-profiles.aspx $\quad$ (Last accessed on 19 June 2014)

Jain, A. (2001). Corruption: a review. Journal of Economic Surveys, 15(1), 71-121.

Jeanjean, T., \& Stolowy, H. (2008). Do accounting standards matter? An exploratory analysis of earnings management before and after IFRS adoption. Journal of Accounting \& Public Policy, 27(6), 480-494.

Kaufmann, D., \& Wei, S. J. (1999). Does 'grease money' speed up the wheels of commerce? NBER Working Paper Series.

Kaufmann, D., Kraay, A., \& Mastruzzi, M. (2011). The worldwide governance indicators: Methodology and analytical issues. Hague Journal on the Rule of Law, 3, 220-246.

Kaufmann, D., Kraay, A., \& Mastruzzi, M. (2012). The worldwide governance indicators (1996-2012). Available at http://info.worldbank.org/governance/wgi/index.aspx\#home

Kehoe, W. J. (1998). The environment of ethics in global business. Journal of Business and Behavioral Science, 2(1), 47-56. 
Kimbro, M.B. (2002). A cross-country empirical investigation of corruption and its relation to economic, cultural, and monitoring institutions: An examination of the role of accounting and financial statements quality. Journal of Accounting Auditing and Finance, 17(4), 325-75.

Knack, S. (2007). Measuring corruption: a critique of indicators in Eastern Europe and Central Asia. Journal of Public Policy, 27(3), 255 - 291.

La Porta, R., Lopez-de-Silanes, F., \& Shleifer, A.S, \& Vishny, R. (1999). The quality of government. The Journal of Law, Economics, \& Organization, 15(1), 222-279.

La Porta, R., Lopez-de-Silanes, F., \& Shleifer, A.S, \& Vishny, R. (2000). Investor protection and corporate governance. Journal of Financial Economics, 58(1-2), 3-27.

Lambert-Mogiliansky, A. (2002). Why firms pay occasional bribes: The connection economy. European Journal of Political Economy, 18(1), 47-60.

Lambsdorff, J. G. (2006). Consequences and causes of corruption: what do we know from a cross-section of countries? In International Handbook on the Economics of Corruption, Rose-Ackerman (ed.), Edward Elgar, Cheltenham, UK.

Lederman, D., Loayza, N., \& Soares, R. S. (2005). Accountability and corruption political institutions matter. Economics \& Politics, 17(1), 1-35.

Leuz, C. (2003). IFRS versus US GAAP: information asymmetry-based evidence from Germany's new market. Journal of Accounting Research, 41(2), 445-472.

Li. S. (2010). Does mandatory adoption of international financial reporting standards in the European Union reduce the cost of equity capital? The Accounting Review, 85(2): 607636.

Malagueño, R., Albrecht, C., Ainge, C., \& Stephens, N. (2010). Accounting and corruption: a cross-country analysis. Journal of Money Laundering Control, 13(4), 372-393.

Morris, R.D., Susilowati, I., \& Gray, S.J. (2014). The impact of IFRS adoption on corporate disclosure levels in the Asian region. Working paper (University of New South Wales).

Mauro, P. (1995). Corruption and Growth. Quarterly Journal of Economics, 110(3), 681-712. 
Mauro, P. (1997). The effect of corruption on growth, investment and growth expenditure: a cross country analysis. In K.A. Elliott (Ed.), Corruption in Global Economy, 83-107, Washington, DC: Institute for International Economics.

Mo, P.H. (2001). Corruption and economic growth. Journal of Comparative Economics, 29(1), 66-79.

Olken, B.A., \& Pande, R. (2011). Corruption in developing countries. Working paper. National Bureau of Economic Research.

Paldam, M. (2002). The cross-country pattern of corruption: Economics, culture, and the see saw dynamics. European Journal of Political Economy, 18(2), 215-240.

Park, H. (2003). Determinants of corruption: A cross-national analysis. Multinational

Business Review, 11(2), 29-48.

Preiato, J., Brown, P., \& Tarca, A. (2015). A comparison of between-country measures of legal setting and enforcement of accounting standards. Journal of Business Finance \& Accounting, 42(1 \& 2), 1-50.

PricewaterhouseCoopers (2013). IFRS adoption by country. Available at http://www.pwc.com/en US/us/issues/ifrs-reporting/publications/assets/pwc-ifrsby-country-apr-2013.pdf (last accessed on 17 June 2014).

Rock, M. T., \& Bonnett, H. (2004). The comparative politics of corruption: Accounting for the East Asian paradox in empirical studies of corruption, growth and investment. World Development, 32(6), 999-1017.

Rose-Ackerman, S. (2001). Political corruption and democratic structures. In A. K. Jain (Ed), The Political Economy of Corruption, 35-62, Routledge, London.

Rose-Ackerman, S. (2003). Corruption. In C. K. Rowley and F. Schneider (Ed), The Encyclopaedia of Public Choice Corruption, 67-76, Kluwer Academic Publishers.

Sandholtz, W., \& Koetzle, W. (2000). Accounting for corruption: economic structure, democracy, and trade. International Studies Quarterly, 44(1), 31-50.

Serra, D. (2006). Empirical determinants of corruption: A sensitivity analysis. Public Choice, 126(1), 225-256. 
Shleifer, A., \& Vishny, R. (1993). Corruption. The Quarterly Journal of Economics, 108(3), 599617.

Smarzynska, B. K., \& Wei, S.J. (2000). Corruption and composition of foreign direct investment: Firm-level evidence, NBER Working Paper Series.

Sung, H. (2004). Democracy and political corruption: A cross-national comparison. Crime, Law \& Social Change 41, 179-194.

Tanzi, V. (1998). Corruption around the world: Consequences, scope, and cures. Staff Papers - International Monetary Fund 45(4), 559-594.

Tanzi, V. and Davoodi, H. (2001). Corruption, growth, and public finances. In A. K. Jain (Ed), The Political Economy of Corruption, 35-62, Routledge, London.

The World Bank. (2009). Data and Indicators 2009. Retrieved from http://data.worldbank.org/indicator

The World Bank. (2010). Data and Indicators 2010. Retrieved from http://data.worldbank.org/indicator

The World Bank (2010). Doing Business Available at http://www.doingbusiness.org/reports/global-reports/doing-business-2010

The World Bank (2011). Doing Business. Available at

http://www.doingbusiness.org/reports/global-reports/doing-business-2011.

The World Bank. (2012). Doing Business. Available at

http://www.doingbusiness.org/reports/global-reports/doing-business-2012.

The World Bank. (2011). Data and Indicators 2011. Retrieved from

http://data.worldbank.org/indicator

The World Bank. (2012). Extent of disclosure index. Available at

http://data.worldbank.org/indicator/IC.BUS.DISC.XQ

Transparency International (2015). Corruption perceptions index 2014: Frequently asked questions. Available at http://www.transparency.org/cpi2014/in detail\#myAnchor2 (last accessed on 11 October 2015). 
Treisman, D. (2007). What have we learned about the causes of corruption from ten years of cross-national empirical research? Annual Review of Political Science, 10, 211-244.

U.S. Central Intelligence Agency (2011). World Factbook. Available at https://www.cia.gov/library/publications/download/download-2011/

Verlegh, P.W.J. \& Steenkamp, J.E.M. (1999). A review and meta-analysis of country-of-origin research. Journal of Economic Psychology, 20, 521-546.

Wei, S. J. (2000). How taxing is corruption on international investors? The Review of Economics and Statistics, 82(1), 1-11.

$\mathrm{Wu}, \mathrm{X}$. (2005a). Firm accounting practices, accounting reforms and corruption in Asia. Policy and Society, 24(3), 53-78.

$\mathrm{Wu}, \mathrm{X}$. (2005b). Corporate governance and corruption: A cross-country analysis. Governance: An International Journal of Policy, Administration and Institutions, 18(2), 151-170.

Zhao, J.H., Kim, S.H., \& Du, J. (2003). The impact of corruption and transparency on foreign direct investment: An empirical analysis. Management International Review, 43(1), 4162.

Zeff, S.A., \& Nobes, C.W. (2010). Commentary: Has Australia (or any other jurisdiction) 'adopted' IFRS? Australian Accounting Review, 53(2), 178-184. 
Table 1

Description of variables and data sources.

\begin{tabular}{|c|c|c|c|}
\hline Variable & Measure & Description of variable & Data source \\
\hline \multicolumn{4}{|c|}{ Dependent variable } \\
\hline Corruption & Low_Corrup & $\begin{array}{l}\text { "Control of corruption" index }(2009,2010 \text {, and } \\
\text { 2011). This index measures the perception of the } \\
\text { extent to which public power is exercised for } \\
\text { private gain, including both petty and grand form of } \\
\text { corruption, as well as "capture of the state by elites } \\
\text { and private interest." The index is expressed in } \\
\text { standard normal units ranging from around }-2.5 \text { to } \\
2.5 \text {. However, in our sample, the index ranges from } \\
-1.439 \text { to } 2.484 \text {, with higher scores indicating } \\
\text { perception of less corruption. }\end{array}$ & Kaufmann et al., 2012 \\
\hline \multicolumn{4}{|c|}{ Independent variables } \\
\hline \multirow{3}{*}{$\begin{array}{l}\text { Accounting } \\
\text { Environment }\end{array}$} & A_Env & Aggregate score of two measures: & \\
\hline & 1. IFRS_EXP & $\begin{array}{l}\text { This measure reflects the number of years since a } \\
\text { country adopted mandatory IFRS. Measures were } \\
\text { taken at } 31 \text { December, 2009, 2010, and } 2011 \text {. } \\
\text { Although all of our sample countries adopted IFRS } \\
\text { by } 2011 \text {, we assign a score of zero to those countries } \\
\text { that had not adopted IFRS by } 2009 \text { or } 2010 \text {. }\end{array}$ & $\begin{array}{l}\text { "IFRS Adoption by } \\
\text { Country" survey } \\
\text { conducted by } \\
\text { PricewaterhouseCoopers } \\
\text { in April } 2013\end{array}$ \\
\hline & 2. DISC & $\begin{array}{l}\text { The World Bank's measure of the extent of } \\
\text { disclosure in protecting minority shareholders } \\
\text { through transparency and disclosure of related- } \\
\text { party transactions. The index ranges from } 0 \text { to } 10 \\
\text { with higher scores indicating greater disclosure. }\end{array}$ & $\begin{array}{l}\text { Doing Business Report, } \\
\text { The World Bank, 2010, } \\
\text { 2011, } 2012\end{array}$ \\
\hline \multicolumn{4}{|l|}{ Control variables } \\
\hline \multirow{3}{*}{$\begin{array}{l}\text { Political } \\
\text { institutions }\end{array}$} & Pol & Aggregate score of two measures: & \\
\hline & 1. $V_{-} A$ & $\begin{array}{l}\text { Voice and accountability index for } 2009,2010 \text {, and } \\
2011 \text {. It measures "the extent to which country's } \\
\text { citizens are able to participate in selecting their } \\
\text { government, as well as freedom of expression, } \\
\text { freedom of association and a free media." It ranges } \\
\text { from - } 2.15808 \text { to } 1.63031 \text {, with higher scores } \\
\text { indicating greater voice and accountability and vice- } \\
\text { versa. }\end{array}$ & Kaufmann et al., 2012 \\
\hline & 2.R_LAW & $\begin{array}{l}\text { Rule of law index for } 2009,2010 \text {, and } 2011 \text {. It } \\
\text { measures the extent to which agents have } \\
\text { confidence in and abide by the rules of society, and } \\
\text { in particular the quality of contract enforcement, } \\
\text { the police, and the courts, as well as the likelihood } \\
\text { of crime and violence. It ranges from - } 1.82 \text { to } 1.94 \text {, } \\
\text { with higher scores indicating strong rule of law and } \\
\text { vice-versa. }\end{array}$ & Kaufmann et al., 2012 \\
\hline Political system & DEMOCRACY & $\begin{array}{l}\text { Dummy variable that is set equal to } 1 \text { for democratic } \\
\text { countries and } 0 \text { otherwise. }\end{array}$ & $\begin{array}{l}\text { The World Factbook, U.S. } \\
\text { Central Intelligence } \\
\text { Agency (CIA), } 2011\end{array}$ \\
\hline $\begin{array}{l}\text { Economic } \\
\text { Development }\end{array}$ & $E C O \_D E V$ & $\begin{array}{l}\text { GDP per capita is gross domestic product divided by } \\
\text { midyear population. GDP is the sum of gross value } \\
\text { added by all resident producers in the economy plus } \\
\text { any product taxes and minus any subsidies not } \\
\text { included in the value of the products. It is calculated } \\
\text { without making deductions for depreciation of } \\
\text { fabricated assets or depletion and degradation of } \\
\text { natural resources. Data are in current U.S. dollars. }\end{array}$ & The World Bank, 2012 \\
\hline
\end{tabular}




\begin{tabular}{|c|c|c|c|}
\hline $\begin{array}{l}\text { Investor } \\
\text { Protection }\end{array}$ & $I N V_{-} P R O$ & $\begin{array}{l}\text { Extent of director liability index is used as the proxy } \\
\text { for investor protection. Director liability index } \\
\text { measures a plaintiff's ability to hold directors of a } \\
\text { firm liable for damages to the firm. That is, it } \\
\text { measures the strength of minority shareholders' } \\
\text { protection against directors' misuse of corporate } \\
\text { assets for personal gain. The data come from a } \\
\text { survey of corporate lawyers and are based on } \\
\text { company laws, court rules of evidence, and } \\
\text { securities regulations. The index ranges from } 0 \text { to } \\
10 \text { with higher values indicating stronger investor } \\
\text { protection. }\end{array}$ & $\begin{array}{l}\text { Doing Business Report, } \\
\text { The World Bank, 2010, } \\
2011,2012\end{array}$ \\
\hline Tax & TAX_RATE & Corporate tax rate on profit & $\begin{array}{l}\text { Doing Business Report, } \\
\text { The World Bank, 2010, } \\
2011,2012^{14}\end{array}$ \\
\hline \multirow[t]{4}{*}{ Culture } & $\begin{array}{l}\text { Power distance } \\
\text { (PD) }\end{array}$ & $\begin{array}{l}\text { It measures the response of people to inequality and } \\
\text { the extent to which the less-powerful members } \\
\text { expect, accept, or even prefer the fact that power is } \\
\text { distributed unequally. Cultures with an unequal } \\
\text { distribution of power tend to discourage } \\
\text { questioning authority. }\end{array}$ & Hofstede (2011) \\
\hline & $\begin{array}{l}\text { Individualism } \\
\text { (IND) }\end{array}$ & $\begin{array}{l}\text { It refers to the extent that individuals are integrated } \\
\text { into groups. It reflects that countries with high level } \\
\text { of individualism places a higher value of individual } \\
\text { achievement and responsibility. Individualistic } \\
\text { societies have a greater tolerance of diversity and } \\
\text { differences of opinion. The opposite of } \\
\text { individualism is collectivism where group or } \\
\text { societal norms take precedence over individual } \\
\text { views. }\end{array}$ & Hofstede (2011) \\
\hline & $\begin{array}{l}\text { Uncertainty } \\
\text { avoidance } \\
\text { (UNAVOID) }\end{array}$ & $\begin{array}{l}\text { It measures the society's tolerance of uncertainty or } \\
\text { unknown situation. Societies that have high } \\
\text { uncertainty avoidances are those in which people } \\
\text { feel uncomfortable in unpredicted situations which } \\
\text { result to unwillingness to challenge authority. }\end{array}$ & Hofstede (2011) \\
\hline & Secrecy (SEC) & $\begin{array}{l}\text { Similar to Hope et. al. (2008) measures. As the sum } \\
\text { of uncertainty avoidance (UNAVOID) and power } \\
\text { distance }(P D) \text { scores less the Individualism (IND) } \\
\text { score. }\end{array}$ & Hofstede (2011) \\
\hline
\end{tabular}

14 We collected the relevant extent of disclosure index data for the period 2009-2011 from Doing Business Reports of 2010-2012 because the Reports contain one-year-lagged data. 
Table 2

Descriptive statistics of key variables.

\begin{tabular}{|c|c|c|c|c|c|c|}
\hline & Low_Corrup & $V_{-} A$ & $R \_L A W$ & IFRS_EXP & DISC & $E C O \_D E V$ \\
\hline \multicolumn{7}{|l|}{ Years: } \\
\hline Mean & 0.278 & 0.201 & 0.246 & 3.830 & 5.706 & 17375.31 \\
\hline Median & 0.096 & 0.409 & 0.147 & 5.000 & 6.075 & 8292.46 \\
\hline$S D$ & 1.019 & 0.928 & 0.977 & 2.701 & 2.454 & 20356.11 \\
\hline Minimum & -1.439 & -2.158 & -1.820 & 0.000 & 1.000 & 323.45 \\
\hline Maximum & 2.484 & 1.630 & 1.970 & 11.00 & 10.000 & 100541.24 \\
\hline$N$ & 312 & 312 & 312 & 312 & 312 & 312 \\
\hline \multicolumn{7}{|l|}{ Year: 2011} \\
\hline Mean & 0.277 & 0.194 & 0.251 & 4.810 & 5.683 & 19102.79 \\
\hline Median & 0.089 & 0.372 & 0.141 & 6.500 & 6.000 & 8755.37 \\
\hline$S D$ & 1.012 & 0.936 & 0.975 & 2.626 & 2.556 & 22623.57 \\
\hline Minimum & -1.364 & -2.158 & -1.755 & 1.000 & 1.000 & 373.98 \\
\hline Maximum & 2.421 & 1.630 & 1.959 & 11.000 & 10.000 & 114508.38 \\
\hline$N$ & 104 & 104 & 104 & 104 & 104 & 104 \\
\hline \multicolumn{7}{|l|}{ Year: 2010} \\
\hline Mean & 0.276 & 0.202 & 0.245 & 3.810 & 5.723 & 16971.73 \\
\hline Median & 0.088 & 0.383 & 0.146 & 5.500 & 6.124 & 8292.46 \\
\hline$S D$ & 1.022 & 0.930 & 0.983 & 2.625 & 2.421 & 19654.91 \\
\hline Minimum & -1.336 & -2.154 & -1.790 & 0.000 & 1.000 & 325.05 \\
\hline Maximum & 2.379 & 1.609 & 1.970 & 10.000 & 10.000 & 103574.17 \\
\hline$N$ & 104 & 104 & 104 & 104 & 104 & 104 \\
\hline \multicolumn{7}{|l|}{ Year: 2009} \\
\hline Mean & 0.282 & 0.208 & 0.242 & 2.880 & 5.713 & 10684.94 \\
\hline Median & 0.115 & 0.410 & 0.147 & 4.500 & 6.102 & 7486.24 \\
\hline$S D$ & 1.035 & 0.928 & 0.983 & 2.525 & 2.384 & 18713.83 \\
\hline Minimum & -1.439 & -2.158 & -1.820 & 0.000 & 1.000 & 323.45 \\
\hline Maximum & 2.484 & 1.573 & 1.969 & 9.000 & 10.000 & 100541.24 \\
\hline$N$ & 104 & 104 & 104 & 104 & 104 & 104 \\
\hline
\end{tabular}

All variable definitions appear in Table 1. 
Table 3

Pearson's correlation matrix.

Panel A: 2009-2011

\begin{tabular}{|c|c|c|c|c|c|c|}
\hline Variables & Low_Corrup & $V_{-} A$ & $R \_L A W$ & $I F R S \_E X P$ & $D I S C$ & $E C O \_D E V$ \\
\hline$V_{-} A$ & $0.242^{* * *}$ & & & & & \\
\hline & & 1 & & & & \\
\hline$R \_L A W$ & $0.346^{* * *}$ & $0.185^{* * *}$ & 1 & & & \\
\hline IFRS_EXP & $0.568^{* * *}$ & $0.201^{* * *}$ & $0.260^{* * *}$ & 1 & & \\
\hline DISC & $0.230^{* * *}$ & 0.027 & $0.230^{* * *}$ & 0.061 & 1 & \\
\hline$E C O \_D E V$ & $0.471^{* * *}$ & $0.320^{* * *}$ & $0.274^{* * *}$ & $0.285^{* * *}$ & $0.218^{* * *}$ & 1 \\
\hline
\end{tabular}

Panel B: 2011

\begin{tabular}{|c|c|c|c|c|c|c|}
\hline Variables & Low_Corrup & $\bar{V} V_{-} A$ & $R \_L A W$ & IFRS_EXP & DISC & $E C O \_D E V$ \\
\hline$\overline{V_{-} A}$ & $0.244^{* * *}$ & & & & & \\
\hline & & 1 & & & & \\
\hline$R \_L A W$ & $0.344^{* * *}$ & $0.189^{* * *}$ & 1 & & & \\
\hline IFRS_EXP & $0.623^{* * *}$ & $0.210^{* * *}$ & $0.300^{* * *}$ & 1 & & \\
\hline DISC & $0.236^{* *}$ & 0.029 & $0.247^{* * *}$ & 0.04 & 1 & \\
\hline$E C O \_D E V$ & $0.320^{* * *}$ & $0.356^{* * *}$ & $0.298^{* * *}$ & $0.269^{* * *}$ & $0.234^{* *}$ & 1 \\
\hline
\end{tabular}

Panel C: 2010

\begin{tabular}{|c|c|c|c|c|c|c|}
\hline Variables & Low_Corrup & $V_{-} A$ & $R \_L A W$ & IFRS_EXP & $D I S C$ & $E C O \_D E V$ \\
\hline $\bar{V}{ }_{-} A$ & $0.251^{* * *}$ & & & & & \\
\hline$R \_L A W$ & $0.342^{* * *}$ & $\begin{array}{c}1 \\
0.192^{* * *}\end{array}$ & 1 & & & \\
\hline IFRS_EXP & $0.663^{* * *}$ & $0.229^{* * *}$ & $0.290^{* * *}$ & 1 & & \\
\hline DISC & $0.226^{* *}$ & 0.032 & $0.228^{* *}$ & 0.060 & 1 & \\
\hline ECO_DEV & $0.354^{* * *}$ & $0.332^{* * *}$ & $0.282^{* * *}$ & $0.297^{* * *}$ & $0.255^{* *}$ & 1 \\
\hline \multicolumn{7}{|c|}{ Panel D: 2009} \\
\hline Variables & Low_Corrup & $V_{-} A$ & $R \_L A W$ & $I F R S \_E X P$ & $D I S C$ & $E C O \_D E V$ \\
\hline$V_{-} A$ & $0.250^{* * *}$ & 1 & & & & \\
\hline$R_{-} L A W$ & $0.344^{* * *}$ & $0.187^{* * *}$ & 1 & & & \\
\hline IFRS_EXP & $0.589 * * *$ & $0.219^{* * *}$ & $0.270^{* * *}$ & 1 & & \\
\hline DISC & $0.210^{* *}$ & 0.010 & $0.210^{* *}$ & 0.040 & 1 & \\
\hline$E C O \_D E V$ & $0.341^{* * *}$ & $0.310^{* * *}$ & $0.291^{* * *}$ & $0.289^{* * *}$ & $0.249^{* * *}$ & 1 \\
\hline
\end{tabular}

Note: All variable definitions appear in Table $1 . *{ }^{* *}$, and ${ }^{* * *}$ denote statistical significance at the $10 \%, 5 \%$, and $1 \%$ levels, respectively. 
Table 4

Results of OLS regressions on corruption perception (dependent variable is low corruption; year: 2011).

$L o w_{-}$Corrup $=\alpha_{0}+\alpha_{1}(\mathrm{Pol})+\alpha_{2}\left(E C O_{-} D E V\right)+\varepsilon$

$L o w_{-}$Corrup $=\alpha_{0}+\alpha_{1}(P o l)+\alpha_{2}\left(E C O_{-} D E V\right)+\alpha_{3}\left(A_{-} E N V\right)+\varepsilon$

$L o w_{-}$Corrup $=\alpha^{\alpha} 0+\alpha_{1}(P o l)+\alpha_{2}\left(E C O \_D E V\right)+\alpha_{3}\left(I F R S_{-} E X P\right)+\varepsilon$

$L o w_{-}$Corrup $=\alpha^{\prime}+\dot{\alpha}_{1}(P o l)+\alpha_{2}\left(E C O_{-} D E V\right)+\dot{\alpha}_{3}(D I S C)+\varepsilon$

$L o w_{-}$Corrup $=\psi_{0}+\psi_{1}(\mathrm{Pol})+\psi_{2}\left(E C O_{-} D E V\right)+\psi_{3}\left(I F R S_{-} E X P\right)+\psi_{4}(D I S C)+\varepsilon$

\begin{tabular}{|c|c|c|c|c|c|c|}
\hline Variable(s) & $\begin{array}{l}\text { Expected } \\
\text { Sign }\end{array}$ & $\begin{array}{c}\text { Model } 1 \\
\text { Coefficient } \\
(t \text {-statistic) }\end{array}$ & $\begin{array}{c}\text { Model } 2 \\
\text { Coefficient } \\
(t \text {-statistic) }\end{array}$ & $\begin{array}{c}\text { Model } 3 \\
\text { Coefficient } \\
(t \text {-statistic })\end{array}$ & $\begin{array}{c}\text { Model } 4 \\
\text { Coefficient } \\
(t \text {-statistic) }\end{array}$ & $\begin{array}{c}\text { Model } 5 \\
\text { Coefficient } \\
\text { (t-statistic) }\end{array}$ \\
\hline Intercept & $?$ & $\begin{array}{c}-0.942^{* *} \\
(-2.219)\end{array}$ & $\begin{array}{c}-0.982^{* * *} \\
(-2.381)\end{array}$ & $\begin{array}{c}-0.973^{* *} \\
(-2.318)\end{array}$ & $\begin{array}{l}-0.951^{* *} \\
(-2.257)\end{array}$ & $\begin{array}{l}-0.987^{* * *} \\
(2.383)\end{array}$ \\
\hline Pol & + & $\begin{array}{c}0.863^{* * *} \\
(11.283)\end{array}$ & $\begin{array}{c}0.822^{* * *} \\
(10.832)\end{array}$ & $\begin{array}{l}0.805^{* * *} \\
(9.858)\end{array}$ & $\begin{array}{c}0.872^{* * *} \\
(11.463)\end{array}$ & $\begin{array}{c}0.808^{* * *} \\
(10.027)\end{array}$ \\
\hline$E C O \_D E V$ & - & $\begin{array}{l}0.114^{* * *} \\
(2.363)\end{array}$ & $\begin{array}{r}0.074^{*} \\
(1.506)\end{array}$ & $\begin{array}{c}0.096^{* *} \\
(1.986)\end{array}$ & $\begin{array}{c}0.096^{* *} \\
(1.965)\end{array}$ & $\begin{array}{r}0.074^{*} \\
(1.490)\end{array}$ \\
\hline$A_{-} E N V$ & + & & $\begin{array}{l}0.039^{* * *} \\
(2.629)\end{array}$ & & & \\
\hline IFRS_EXP & + & & & $\begin{array}{l}0.048^{* * *} \\
(2.954)\end{array}$ & & $\begin{array}{c}0.047^{* *} \\
(2.111)\end{array}$ \\
\hline DISC & + & & & & $\begin{array}{c}0.039^{* *} \\
(1.765)\end{array}$ & $\begin{array}{c}0.034^{* *} \\
(1.891)\end{array}$ \\
\hline Adj. $R^{2}$ & & 0.735 & 0.820 & 0.813 & 0.812 & 0.821 \\
\hline $\begin{array}{l}F \text {-statistic ( } p \text { - } \\
\text { value) } \\
N\end{array}$ & & $\begin{array}{c}217.635 \\
(0.000) \\
104 \\
\end{array}$ & $\begin{array}{c}160.697 \\
(0.000) \\
104 \\
\end{array}$ & $\begin{array}{c}151.515 \\
(0.000) \\
104\end{array}$ & $\begin{array}{c}150.749 \\
(0.000) \\
104 \\
\end{array}$ & $\begin{array}{c}119.519 \\
(0.000) \\
104 \\
\end{array}$ \\
\hline
\end{tabular}

Note: All variable definitions appear in Table 1.

$*, * *$, and $* * *$ denote statistical significance at the $10 \%, 5 \%$, and $1 \%$ levels (one-tailed test), respectively. 
Table 5

Results of OLS regressions on corruption perception (dependent variable is low corruption; year: 2010).

\begin{tabular}{|c|c|c|c|c|c|c|}
\hline \multicolumn{6}{|c|}{ Low_Corrup $=\alpha_{0}+\alpha_{1}(\mathrm{Pol})+\alpha_{2}\left(E C O_{-} D E V\right)+\varepsilon$} & (1) \\
\hline \multicolumn{6}{|c|}{ Low_Corrup $=\alpha_{0}+\alpha_{1}($ Pol $)+\alpha_{2}\left(E C O_{-} D E V\right)+\alpha_{3}\left(A_{-} E N V\right)+\varepsilon$} & $(2)$ \\
\hline \multicolumn{6}{|c|}{ Low_Corrup $=\dot{\alpha}_{0}+\dot{\alpha}_{1}(\mathrm{Pol})+\dot{\alpha}_{2}\left(E C O_{-} D E V\right)+\dot{\alpha}_{3}($ IFRS_EXP $)+\varepsilon$} & (3) \\
\hline \multicolumn{6}{|c|}{$L_{o} w_{-}$Corrup $=\alpha_{0}+\dot{\alpha}_{1}(\mathrm{Pol})+\dot{\alpha}_{2}\left(E C O_{-} D E V\right)+\dot{\alpha}_{3}(\mathrm{DISC})+\varepsilon$} & $(4)$ \\
\hline \multicolumn{6}{|c|}{ Low $_{-}$Corrup $=\psi_{0}+\psi_{1}($ Pol $)+\psi_{2}\left(E C O_{-} D E V\right)+\psi_{3}($ IFRS_EXP $)+\psi_{4}($ DISC $)+\varepsilon$} & $(5)$ \\
\hline $\operatorname{Variable}(\mathrm{s})$ & $\begin{array}{c}\text { Expected } \\
\text { Sign }\end{array}$ & $\begin{array}{c}\text { Model 1 } \\
\text { Coefficient } \\
\text { (t-statistic) }\end{array}$ & $\begin{array}{c}\text { Model } 2 \\
\text { Coefficient } \\
\text { (t-statistic) }\end{array}$ & $\begin{array}{c}\text { Model } 3 \\
\text { Coefficient } \\
\text { (t-statistic) }\end{array}$ & $\begin{array}{c}\text { Model } 4 \\
\text { Coefficient } \\
\text { (t-statistic) }\end{array}$ & $\begin{array}{c}\text { Model } 5 \\
\text { Coefficient } \\
\text { (t-statistic) }\end{array}$ \\
\hline Intercept & $?$ & $\begin{array}{l}-0.912^{* *} \\
(-2.204)\end{array}$ & $\begin{array}{l}-0.901^{* *} \\
(-2.025)\end{array}$ & $\begin{array}{l}-0.925^{* * *} \\
(-2.954)\end{array}$ & $\begin{array}{l}-0.930^{* * *} \\
(-2.596)\end{array}$ & $\begin{array}{l}-0.910^{* * *} \\
(-2.381)\end{array}$ \\
\hline Pol & + & $\begin{array}{c}0.802^{* * *} \\
(10.258)\end{array}$ & $\begin{array}{l}0.810^{* * *} \\
(9.985)\end{array}$ & $\begin{array}{l}0.800^{* * * *} \\
(10.124)\end{array}$ & $\begin{array}{c}0.812^{* * *} \\
(10.452)\end{array}$ & $\begin{array}{c}0.809^{* * *} \\
(10.011)\end{array}$ \\
\hline$E C O \_D E V$ & + & $\begin{array}{l}0.101^{* *} \\
(2.195)\end{array}$ & $\begin{array}{c}0.072 \\
(1.420)\end{array}$ & $\begin{array}{c}0.085^{* *} \\
(1.786)\end{array}$ & $\begin{array}{c}0.088^{* *} \\
(1.885)\end{array}$ & $\begin{array}{c}0.073^{*} \\
(1.541)\end{array}$ \\
\hline$A_{-} E N V$ & + & & $\begin{array}{l}0.401^{* * *} \\
(2.754)\end{array}$ & & & \\
\hline IFRS_EXP & + & & & $\begin{array}{l}0.049^{* * *} \\
(2.994)\end{array}$ & & $\begin{array}{c}0.048^{* *} \\
(2.101)\end{array}$ \\
\hline DISC & + & & & & $\begin{array}{l}0.038^{* *} \\
(1.725)\end{array}$ & $\begin{array}{c}0.035^{* *} \\
(1.901)\end{array}$ \\
\hline Adj. $R^{2}$ & & 0.725 & 0.830 & 0.818 & 0.815 & 0.828 \\
\hline $\begin{array}{l}F \text {-statistic ( } p \text { - } \\
\text { value) }\end{array}$ & & $\begin{array}{r}198.323 \\
(0.000)\end{array}$ & $\begin{array}{r}148.408 \\
(0.000)\end{array}$ & $\begin{array}{r}138.780 \\
(0.000)\end{array}$ & $\begin{array}{r}138.588 \\
(0.000)\end{array}$ & $\begin{array}{r}110.327 \\
(0.000)\end{array}$ \\
\hline$N$ & & 104 & 104 & 104 & 104 & 104 \\
\hline
\end{tabular}

Note: All variable definitions appear in Table 1.

$*, * *$, and ${ }^{* * *}$ denote statistical significance at the $10 \%, 5 \%$, and $1 \%$ levels (one-tailed test), respectively. 
Table 6

Results of OLS regressions on corruption perception (dependent variable is low corruption; year: 2009).

$L o w_{-}$Corrup $=\alpha_{0}+\alpha_{1}(\mathrm{Pol})+\alpha_{2}\left(E C O_{-} D E V\right)+\varepsilon$

$L o w_{-}$Corrup $=\alpha_{0}+\alpha_{1}(\mathrm{Pol})+\alpha_{2}\left(E C O_{-} D E V\right)+\alpha_{3}\left(A_{-} E N V\right)+\varepsilon$

$L o w_{-}$Corrup $=\alpha^{\prime} o_{0}+\alpha_{1}(P o l)+\alpha_{2}\left(E C O \_D E V\right)+\alpha^{\prime}{ }_{3}\left(I F R S_{-} E X P\right)+\varepsilon$

Low_Corrup $=\alpha^{\prime}{ }_{0}+\alpha_{1}(P o l)+\alpha_{2}\left(E C O_{-} D E V\right)+\dot{\alpha}_{3}(D I S C)+\varepsilon$

$L o w_{-}$Corrup $=\psi_{0}+\psi_{1}(\mathrm{Pol})+\psi_{2}\left(E C O_{-} D E V\right)+\psi_{3}\left(I F R S_{-} E X P\right)+\psi_{4}(D I S C)+\varepsilon$

(5)

\begin{tabular}{|c|c|c|c|c|c|c|}
\hline Variable(s) & $\begin{array}{l}\text { Expected } \\
\text { Sign }\end{array}$ & $\begin{array}{c}\text { Model } 1 \\
\text { Coefficient } \\
\text { (t-statistic) }\end{array}$ & $\begin{array}{c}\text { Model } 2 \\
\text { Coefficient } \\
\text { (t-statistic) }\end{array}$ & $\begin{array}{c}\text { Model } 3 \\
\text { Coefficient } \\
\text { (t-statistic) }\end{array}$ & $\begin{array}{c}\text { Model } 4 \\
\text { Coefficient } \\
\text { (t-statistic) }\end{array}$ & $\begin{array}{c}\text { Model } 5 \\
\text { Coefficient } \\
\text { (t-statistic) }\end{array}$ \\
\hline Intercept & $?$ & $\begin{array}{l}-0.891^{* *} \\
(-2.184)\end{array}$ & $\begin{array}{l}-0.900^{* * *} \\
(-2.354)\end{array}$ & $\begin{array}{l}-0.918^{* * *} \\
(-3.594)\end{array}$ & $\begin{array}{l}-0.921^{* * *} \\
(-2.765)\end{array}$ & $\begin{array}{l}-0.900^{* * *} \\
(-2.336)\end{array}$ \\
\hline Pol & + & $\begin{array}{c}0.801^{* * *} \\
(11.547)\end{array}$ & $\begin{array}{l}0.801^{* * *} \\
(10.584)\end{array}$ & $\begin{array}{c}0.821^{* * *} \\
(10.215)\end{array}$ & $\begin{array}{c}0.814^{* * *} \\
(10.952)\end{array}$ & $\begin{array}{c}0.802^{* * *} \\
(10.587)\end{array}$ \\
\hline ECO_DEV & + & $\begin{array}{l}0.124^{* * * *} \\
(2.925)\end{array}$ & $\begin{array}{c}0.076^{* *} \\
(1.721)\end{array}$ & $\begin{array}{c}0.084^{* *} \\
(1.814)\end{array}$ & $\begin{array}{c}0.082^{* *} \\
(1.754)\end{array}$ & $\begin{array}{r}0.074^{*} \\
(1.354)\end{array}$ \\
\hline$A \_E N V$ & + & & $\begin{array}{l}0.395^{* * *} \\
(2.957)\end{array}$ & & & \\
\hline IFRS_EXP & + & & & $\begin{array}{l}0.052^{* * *} \\
(2.998)\end{array}$ & & $\begin{array}{l}0.050^{* * *} \\
(2.542)\end{array}$ \\
\hline DISC & + & & & & $\begin{array}{l}0.039^{* *} \\
(1.765)\end{array}$ & $\begin{array}{l}0.037^{* *} \\
(1.901)\end{array}$ \\
\hline Adj. $R^{2}$ & & 0.745 & 0.840 & 0.828 & 0.826 & 0.841 \\
\hline $\begin{array}{l}F \text {-statistic ( } p \text { - } \\
\text { value) }\end{array}$ & & $\begin{array}{r}201.676 \\
(0.000)\end{array}$ & $\begin{array}{r}146.416 \\
(0.000)\end{array}$ & $\begin{array}{r}139.896 \\
(0.000)\end{array}$ & $\begin{array}{r}139.495 \\
(0.000)\end{array}$ & $\begin{array}{r}108.871 \\
(0.000)\end{array}$ \\
\hline$N$ & & 104 & 104 & 104 & 104 & 104 \\
\hline
\end{tabular}

Note: All variable definitions appear in Table 1.

$*, * *$, and ${ }^{* * *}$ denote statistical significance at the $10 \%, 5 \%$, and $1 \%$ levels (one-tailed test), respectively. 
Table 7

Results of OLS regression testing the effect of IFRS experience on corruption perception in developing countries (dependent variable is low corruption, 2011, 2010, 2009).

Low_Corrup $=\alpha_{0}{ }^{\prime}+\dot{\alpha}_{1}\left(\right.$ Pol) $+\dot{\alpha}_{2}$ (Developing)

$$
+\dot{\alpha}_{3}(\text { IFRS_EXP })+\dot{\alpha}_{4}(\text { Developing *IFRS_EXP })+\dot{\alpha}_{5}(\text { DISC })+\varepsilon
$$

\begin{tabular}{lccc}
\hline Variable(s) & $\begin{array}{c}2011 \\
\text { Coefficient } \\
(t \text {-statistic })\end{array}$ & $\begin{array}{c}2010 \\
\text { Coefficient } \\
(t \text {-statistic })\end{array}$ & $\begin{array}{c}2009 \\
\text { Coefficient } \\
(t \text {-statistic })\end{array}$ \\
\hline Intercept & $-0.581^{* * *}$ & $-0.576^{* * *}$ & $-0.448^{* * *}$ \\
Pol & $(-2.594)$ & $(-3.212)$ & $(-2.541)$ \\
& $0.345^{* * *}$ & $0.358^{* * *}$ & $0.371^{* * *}$ \\
Developing & $(12.969)$ & $(11.854)$ & $(11.258)$ \\
& $-0.238^{* *}$ & $-0.240^{* * *}$ & $-0.220^{*}$ \\
IFRS_EXP & $(-1.687)$ & $(-1.689)$ & $(-1.625)$ \\
& $0.077^{* * *}$ & $0.081^{* * *}$ & $0.077^{* * *}$ \\
Developing*IFRS_EXP & $(2.584)$ & $(2.908)$ & $(2.589)$ \\
& $0.088^{* * *}$ & $0.101^{* * *}$ & $0.098^{* * *}$ \\
DISC & $(2.984)$ & $(2.587)$ & $(2.684)$ \\
Adj. $R^{2}$ & $0.048^{* * *}$ & $0.050^{* * *}$ & $0.048^{* * *}$ \\
& $(2.589)$ & $(2.921)$ & $(2.528)$ \\
F-statistic $(p$-value) & 0.634 & 0.651 & 0.610 \\
& & & \\
$N$ & 92.237 & 85.048 & 82.030 \\
& $(0.000)$ & $(0.000)$ & $(0.000)$ \\
& 104 & 104 & 104 \\
\hline
\end{tabular}

Note: Developing is a binary variable coded as 1 for developing countries and 0 for other countries. Countries with per capita GDP below US $\$ 4,528$ in 2009 , below US $\$ 4,887$ in 2010 , and below US $\$ 5,203$ in 2011 were classified as Developing countries. Per capita GDP is based on 2005 purchasing power parity. All other variable definitions appear in Table 1.

${ }^{*},{ }^{* *}$, and ${ }^{* * *}$ denote statistical significance at the 10,5 and $1 \%$ levels (one-tailed test), respectively. 
Table 8

Simultaneous equation analysis (2SLS) of corruption perception, political institutions and accounting environment (year: 2011).

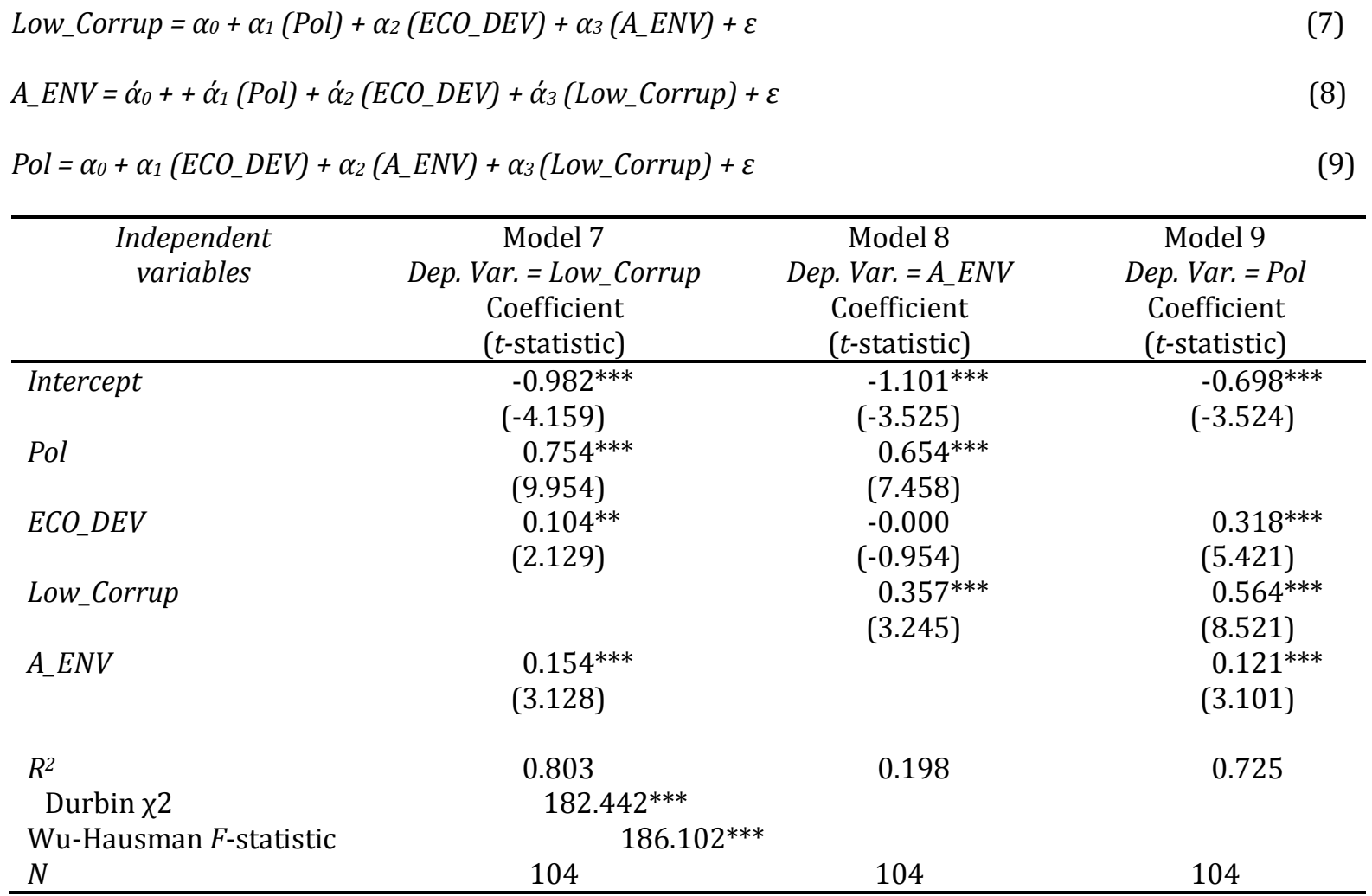

All variable definitions appear in Table 1.

$*, * *$, and ${ }^{* * *}$ denote statistical significance at the $10 \%, 5 \%$, and $1 \%$ levels (one-tailed test), respectively. 
Table 9

Results of OLS regressions incorporating the type of political system, tax rate, investor protection and cultural values (2009-2011).

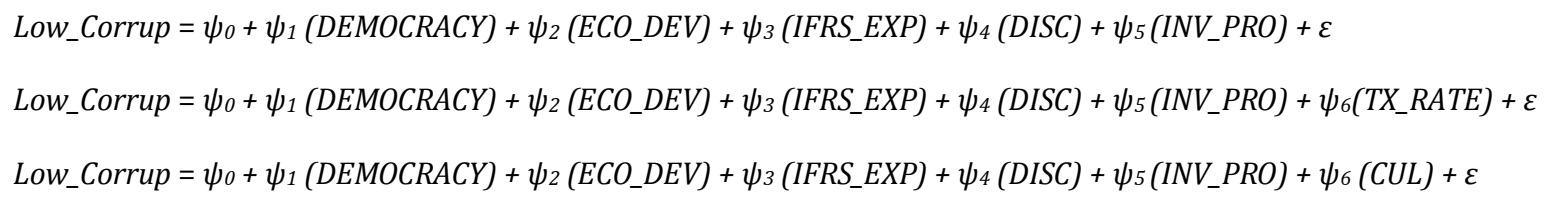

\begin{tabular}{|c|c|c|c|c|c|c|c|}
\hline Variable(s) & $\begin{array}{l}\text { Expected } \\
\text { sign }\end{array}$ & $\begin{array}{c}\text { Model } 9 \\
\text { Coefficient } \\
\text { (t-statistic) }\end{array}$ & $\begin{array}{c}\text { Model 10 } \\
\text { Coefficient } \\
\text { (t-statistic) }\end{array}$ & $\begin{array}{c}\text { Model } 11 \\
\text { Coefficient } \\
\text { (t-statistic) }\end{array}$ & $\begin{array}{c}\text { Model } 11 \\
\text { Coefficient } \\
\text { ( } t \text {-statistic) }\end{array}$ & $\begin{array}{c}\text { Model } 11 \\
\text { Coefficient } \\
\text { (t-statistic) }\end{array}$ & $\begin{array}{c}\text { Model } 11 \\
\text { Coefficient } \\
\text { (t-statistic) }\end{array}$ \\
\hline Intercept & $?$ & $\begin{array}{c}-3.811^{* * *} \\
(-15.204)\end{array}$ & $\begin{array}{c}-4.006^{* * *} \\
(-14.405)\end{array}$ & $\begin{array}{c}-1.248^{* *} \\
(-1.919)\end{array}$ & $\begin{array}{c}-5.061^{* * *} \\
(-12.330)\end{array}$ & $\begin{array}{l}-2.421^{* * *} \\
(-4.355)\end{array}$ & $\begin{array}{l}-2.514^{* * *} \\
(-5.158)\end{array}$ \\
\hline DEMOCRACY & + & $\begin{array}{l}0.322^{* * *} \\
(3.865)\end{array}$ & $\begin{array}{l}0.301^{* * *} \\
(3.580)\end{array}$ & $\begin{array}{c}0.091 \\
(0.911)\end{array}$ & $\begin{array}{l}0.248^{* * *} \\
(2.380)\end{array}$ & $\begin{array}{l}0.427^{* * *} \\
(4.352)\end{array}$ & $\begin{array}{c}0.201^{* *} \\
(2.129)\end{array}$ \\
\hline$E C O \_D E V$ & + & $\begin{array}{c}0.338^{* * *} \\
(10.438)\end{array}$ & $\begin{array}{c}0.350^{* * *} \\
(10.558)\end{array}$ & $\begin{array}{l}0.366^{* * *} \\
(7.755)\end{array}$ & $\begin{array}{l}0.404^{* * *} \\
(7.862)\end{array}$ & $\begin{array}{l}0.438^{* * *} \\
(9.358)\end{array}$ & $\begin{array}{l}0.365^{* * *} \\
(7.766)\end{array}$ \\
\hline IFRS_EXP & + & $\begin{array}{l}0.103^{* * *} \\
(6.786)\end{array}$ & $\begin{array}{l}0.105^{* * *} \\
(6.918)\end{array}$ & $\begin{array}{l}0.078^{* * *} \\
(4.137)\end{array}$ & $\begin{array}{l}0.065^{* * *} \\
(3.152)\end{array}$ & $\begin{array}{l}0.060^{* * *} \\
(3.085)\end{array}$ & $\begin{array}{l}0.060^{* * *} \\
(3.179)\end{array}$ \\
\hline DISC & + & $\begin{array}{l}0.036^{* * *} \\
(2.529)\end{array}$ & $\begin{array}{l}0.037^{* * *} \\
(2.639)\end{array}$ & $\begin{array}{l}0.060^{* * *} \\
(3.767)\end{array}$ & $\begin{array}{l}0.058^{* * *} \\
(3.311)\end{array}$ & $\begin{array}{l}0.046^{* * *} \\
(2.717)\end{array}$ & $\begin{array}{l}0.043^{* * *} \\
(2.609)\end{array}$ \\
\hline$I N V_{-} P R O$ & + & $\begin{array}{l}0.069^{* * *} \\
(4.965)\end{array}$ & $\begin{array}{l}0.071^{* * *} \\
(5.091)\end{array}$ & $\begin{array}{c}0.031^{* *} \\
(1.856)\end{array}$ & $\begin{array}{l}0.055^{* * *} \\
(3.014)\end{array}$ & $\begin{array}{c}0.025^{*} \\
(1.428)\end{array}$ & $\begin{array}{l}0.039^{* *} \\
(2.315)\end{array}$ \\
\hline TAX & - & & $\begin{array}{c}0.002^{*} \\
(1.600)\end{array}$ & & & & \\
\hline$C U L=P D$ & - & & & $\begin{array}{l}-0.638^{* * *} \\
(-6.290)\end{array}$ & & & \\
\hline$C U L=I N D$ & + & & & & $\begin{array}{l}0.212^{* * *} \\
2.447\end{array}$ & & \\
\hline $\begin{array}{l}C U L= \\
\text { UNAVOD }\end{array}$ & - & & & & & $\begin{array}{l}-0.498 * * * \\
(-5.382)\end{array}$ & \\
\hline$C U L=S E C$ & - & & & & & & $\begin{array}{l}-0.265^{* * *} \\
(-6.459)\end{array}$ \\
\hline Adj. $R^{2}$ & & 0.680 & 0.682 & 0.735 & 0.691 & 0.722 & 0.737 \\
\hline $\begin{array}{l}F \text {-statistic } \\
(p \text {-value }) \\
N\end{array}$ & & $\begin{array}{c}133.333 \\
(0.000) \\
312\end{array}$ & $\begin{array}{c}112.103 \\
(0.000) \\
312\end{array}$ & $\begin{array}{c}93.465 \\
(0.000) \\
201\end{array}$ & $\begin{array}{c}75.379 \\
(0.000) \\
201\end{array}$ & $\begin{array}{c}87.753 \\
(0.000) \\
201\end{array}$ & $\begin{array}{c}94.623 \\
(0.000) \\
201\end{array}$ \\
\hline
\end{tabular}

All variable definitions appear in Table 1. The sample size for estimating model (11) drops to 201 observations due to missing data on the various dimensions of culture.

$*, * *$, and ${ }^{* * *}$ denote statistical significance at the $10 \%, 5 \%$, and $1 \%$ levels (one-tailed test), respectively. 
Appendix 1

Corruption perception scores by country and year (for all countries in the sample).

\begin{tabular}{|c|c|c|c|c|c|c|c|}
\hline Country & 2009 & 2010 & 2011 & Country & 2009 & 2010 & 2011 \\
\hline Albania & -0.49 & -0.49 & -0.65 & Korea, Rep. & 0.48 & 0.40 & 0.46 \\
\hline Algeria & -0.55 & -0.49 & -0.51 & Kuwait & 0.42 & 0.40 & 0.13 \\
\hline Angola & -1.42 & -1.32 & -1.34 & $\begin{array}{l}\text { Kyrgyz } \\
\text { Republic }\end{array}$ & -1.23 & -1.11 & -1.15 \\
\hline $\begin{array}{l}\text { Antigua And } \\
\text { Barbuda }\end{array}$ & 1.35 & 1.33 & 1.31 & Lao P.D.R. & -1.26 & -1.21 & -1.19 \\
\hline Armenia & -0.56 & -0.65 & -0.60 & Latvia & 0.13 & 0.13 & 0.19 \\
\hline Australia & 2.08 & 2.04 & 2.08 & Lebanon & -0.83 & -0.86 & -0.89 \\
\hline Austria & 1.76 & 1.63 & 1.44 & Lesotho & 0.16 & 0.18 & 0.18 \\
\hline Azerbaijan & -1.11 & -1.18 & -1.12 & Lithuania & 0.12 & 0.27 & 0.24 \\
\hline Bahamas, The & 1.37 & 1.36 & 1.36 & Luxembourg & 1.99 & 2.06 & 2.17 \\
\hline Bahrain & 0.24 & 0.25 & 0.24 & Madagascar & -0.19 & -0.27 & -0.33 \\
\hline Belarus & -0.64 & -0.73 & -0.72 & Mauritius & 0.63 & 0.65 & 0.59 \\
\hline Belgium & 1.43 & 1.49 & 1.56 & Mexico & -0.30 & -0.37 & -0.40 \\
\hline Bolivia & -0.63 & -0.44 & -0.53 & Mongolia & -0.76 & -0.73 & -0.68 \\
\hline $\begin{array}{l}\text { Bosnia And } \\
\text { Herzegovina }\end{array}$ & -0.37 & -0.32 & -0.31 & Morocco & -0.31 & -0.18 & -0.40 \\
\hline Botswana & 0.92 & 1.00 & 0.99 & Namibia & 0.25 & 0.32 & 0.30 \\
\hline Brazil & -0.12 & 0.00 & 0.15 & Nepal & -0.65 & -0.65 & -0.74 \\
\hline $\begin{array}{l}\text { Brunei } \\
\text { Darussalam }\end{array}$ & 1.02 & 0.89 & 0.88 & Netherlands & 2.17 & 2.18 & 2.16 \\
\hline Bulgaria & -0.25 & -0.21 & -0.23 & New Zealand & 2.46 & 2.40 & 2.34 \\
\hline Cambodia & -1.16 & -1.23 & -1.22 & Norway & 2.00 & 2.10 & 2.17 \\
\hline Canada & 2.08 & 2.10 & 2.00 & Oman & 0.29 & 0.28 & 0.00 \\
\hline Chile & 1.35 & 1.49 & 1.52 & $\begin{array}{l}\text { Papua New } \\
\text { Guinea }\end{array}$ & -1.35 & -1.13 & -1.10 \\
\hline China & -0.54 & -0.60 & -0.56 & Paraguay & -0.83 & -0.74 & -0.71 \\
\hline Costa Rica & 0.71 & 0.65 & 0.58 & Peru & -0.34 & -0.25 & -0.25 \\
\hline Croatia & -0.10 & -0.03 & 0.01 & Philippines & -0.77 & -0.80 & -0.70 \\
\hline Cyprus & 0.93 & 1.00 & 0.89 & Poland & 0.37 & 0.41 & 0.49 \\
\hline Czech Republic & 0.33 & 0.26 & 0.30 & Portugal & 1.04 & 1.03 & 1.08 \\
\hline Denmark & 2.52 & 2.41 & 2.45 & Qatar & 1.72 & 1.57 & 1.08 \\
\hline Dominica & 0.74 & 0.74 & 0.74 & Romania & -0.27 & -0.22 & -0.19 \\
\hline Ecuador & -0.89 & -0.86 & -0.79 & $\begin{array}{l}\text { Russian } \\
\text { Federation }\end{array}$ & -1.09 & -1.06 & -1.04 \\
\hline El Salvador & -0.20 & -0.23 & -0.21 & Rwanda & 0.13 & 0.46 & 0.43 \\
\hline Eritrea & -0.43 & -0.47 & -0.57 & Samoa & 0.11 & 0.13 & 0.11 \\
\hline Estonia & 0.91 & 0.86 & 0.93 & Serbia & -0.31 & -0.29 & -0.25 \\
\hline Fiji & -0.74 & -0.85 & -0.44 & Sierra Leone & -0.94 & -0.77 & -0.82 \\
\hline Finland & 2.30 & 2.18 & 2.22 & Singapore & 2.25 & 2.21 & 2.12 \\
\hline France & 1.42 & 1.44 & 1.52 & $\begin{array}{l}\text { Slovak } \\
\text { Republic }\end{array}$ & 0.23 & 0.24 & 0.24 \\
\hline Gambia, The & -0.56 & -0.56 & -0.50 & Slovenia & 1.02 & 0.85 & 0.90 \\
\hline Georgia & -0.22 & -0.12 & -0.02 & South Africa & 0.14 & 0.09 & 0.03 \\
\hline Germany & 1.72 & 1.74 & 1.71 & Spain & 1.00 & 1.01 & 1.05 \\
\hline Ghana & 0.03 & 0.06 & 0.05 & $\begin{array}{l}\text { St. Kitts And } \\
\text { Nevis }\end{array}$ & 1.06 & 1.04 & 1.05 \\
\hline Greece & 0.01 & -0.16 & -0.18 & $\begin{array}{l}\text { St. Vincent And } \\
\text { The } \\
\text { Grenadines }\end{array}$ & 1.06 & 1.04 & 1.05 \\
\hline Grenada & 0.35 & 0.44 & 0.44 & Suriname & -0.36 & -0.43 & -0.37 \\
\hline
\end{tabular}

Page | 49 


\begin{tabular}{|c|c|c|c|c|c|c|c|}
\hline Guatemala & -0.48 & -0.48 & -0.47 & Sweden & 2.29 & 2.32 & 2.22 \\
\hline $\begin{array}{l}\text { Hong Kong Sar, } \\
\text { China }\end{array}$ & 1.90 & 1.97 & 1.86 & Tajikistan & -1.13 & -1.20 & -1.14 \\
\hline Hungary & 0.34 & 0.25 & 0.32 & Tanzania & -0.44 & -0.54 & -0.63 \\
\hline Iceland & 2.06 & 1.94 & 1.95 & $\begin{array}{l}\text { Trinidad And } \\
\text { Tobago }\end{array}$ & -0.21 & -0.36 & -0.28 \\
\hline Ireland & 1.77 & 1.70 & 1.54 & Turkey & 0.07 & 0.03 & 0.06 \\
\hline Israel & 0.75 & 0.67 & 0.71 & Uganda & -0.89 & -0.90 & -0.90 \\
\hline Italy & 0.13 & 0.00 & 0.08 & $\begin{array}{l}\text { United Arab } \\
\text { Emirates }\end{array}$ & 0.95 & 0.93 & 1.07 \\
\hline Jamaica & -0.44 & -0.38 & -0.29 & $\begin{array}{l}\text { United } \\
\text { Kingdom }\end{array}$ & 1.60 & 1.56 & 1.58 \\
\hline Jordan & 0.22 & 0.06 & 0.10 & $\begin{array}{l}\text { West Bank And } \\
\text { Gaza }\end{array}$ & -0.36 & -0.34 & -0.80 \\
\hline Kazakhstan & -0.88 & -0.98 & -0.98 & Zambia & -0.51 & -0.57 & -0.48 \\
\hline Kenya & -1.08 & -0.94 & -0.95 & Zimbabwe & -1.32 & -1.31 & -1.39 \\
\hline
\end{tabular}

